\title{
Scaling up a successful counseling model in Guatemala
}

Guatemalan Association of Female Physicians (AGMM)

Follow this and additional works at: https://knowledgecommons.popcouncil.org/departments_sbsr-rh

Part of the Demography, Population, and Ecology Commons, International Public Health Commons, and the Maternal and Child Health Commons How does access to this work benefit you? Let us know!

\section{Recommended Citation}

Guatemalan Association of Female Physicians (AGMM). 2004. "Scaling up a successful counseling model in Guatemala," FRONTIERS Final Report. Washington, DC: Population Council. 


\title{
Scaling up a Successful Counseling Model in Guatemala
}

\author{
Asociación Guatemalteca de Mujeres Medicas (AGMM)
}

September 2004

This study was funded by the U.S. AGENCY FOR INTERNATIONAL DEVELOPMENT (USAID) under the terms of Cooperative Agreement number HRN-A-00-98-00012-00 and Population Subagreement Number AI01.10A. The opinions expressed herein are those of the authors and do not necessarily reflect the view of USAID. 


\section{EXECUTIVE SUMMARY}

The general objective of this project was to improve clients' ability to make an informed choice of contraceptive methods by scaling up the use of the balanced counseling strategy in public service delivery institutions in Guatemala. To reach this end, the project provided technical assistance to Calidad en Salud (Quality in Health), the leading reproductive health project in Guatemala, to train service providers in public institutions about the counseling methodology.

The scale-up program included the following activities:

1. Review, modify and reproduce counseling aids, including the counseling algorithm and method-specific cards.

2. Review and develop materials to facilitate training of trainers (TOT) and use of the balanced counseling strategy, including slide shows, manuals, and a user's guide of counseling job aids.

3. A training program implemented in three phases:

a. Phase I: National-level TOT, including 18 field staff from Calidad en Salud, three central-level officers from the Ministry of Health and Social Welfare (MSPAS), and six from the Guatemala Institute of Social Security (IGSS).

b. Phase II: Health area-level TOT, including 46 health area nurses (two per health area) and 73 IGSS service providers.

c. Phase III: District-level training of 268 nurses, 1,029 nurse auxiliaries at health centers and posts, and 127 community-based social workers.

4. Follow-up, supervision, and monitoring of phase II and III activities: six supervisors provided technical assistance to health area-level and district-level nurses in the monitoring and supervision of service providers. As part of these activities, supervisors observed three to five counseling sessions per trainee and provided inservice training. The role of supervisors was to ensure that trainees could demonstrate competence in using the counseling methodology.

The project was conducted in close collaboration with the Calidad en Salud Project. During the length of the project, 200 trainers, 2,275 MSPAS providers, and 73 IGSS providers received training in how to use the counseling strategy. The project successfully introduced the balanced counseling strategy in Guatemala and, as a result, has improved the informed choice of contraceptives in the country. 


\section{CONTENTS}

Executive summary $\quad$ ii

I. BACKGROUND 1

II. OBJECTIVES 2

III. ACTIVITIES 2

IV. FOLLOW-UP, MONITORING, AND SUPERVISION 12

V. PROBLEMS AND SOLUTIONS 16

APPENDIX 1: COUNSELING ALGORITHM AND
METHOD-SPECIFIC CARDS

APPENDIX 2: USER'S GUIDE FOR THE ALGORITHM AND CARDS 24

APPENDIX 3: TRAINING MATERIALS 29

APPENDIX 4: WORKSHOP AGENDA 39

APPENDIX 5: PHASE III TRAINING SCHEDULE 44

APPENDIX 6: SUPERVISION CHECKLIST 47 


\section{BACKGROUND}

In 2001 and 2002, the Population Council's Frontiers in Reproductive Health Program (FRONTIERS) conducted two operations research (OR) projects that tested a family planning counseling strategy supplemented with by job aids in a hospital run by the Guatemalan Institute of Social Security (IGSS) and in a large sample of Ministry of Health and Family Health (MSPAS) health centers. The counseling model, which was named balanced counseling strategy, was developed in Peru as part of a FRONTIERS global agenda study that sought to improve the quality of care in the use of contraceptives.

The improved counseling model includes four components: 1) a counseling guide (algorithm), which includes questions that should be asked during the counseling session; 2) a set of method-specific cards, which provide a quick overview of available methods and help women discard contraceptive choices that they do not want or that are inappropriate for them; 3) method-specific brochures, which contain all of the relevant information about the chosen method; and 4) training and supervision procedures. The balanced counseling strategy achieved excellent results in OR studies conducted with both IGSS and MSPAS. For this reason, the Guatemala Office of the U.S. Agency for International Development (USAID/G) requested that FRONTIERS, in collaboration with the Calidad en Salud project, train all service providers in public institutions in the use of this counseling methodology.

The Calidad en Salud project is a consortium lead by the University Research Corporation (URC) with the participation of Johns Hopkins University Center for Communication Programs (JHU/CCP), EngenderHealth, JHPIEGO, and the Population Council. Calidad en Salud's 25 field staff members include:

- Two family planning advisors (Asesores de Planificación Familiar, APFs), who supervise three to four priority health areas each.

- Seven rural technical advisors (Asistentes Técnicos Rurales, ATRs), who coordinate family planning activities at each of the nine priority health areas (two ATRs coordinate activities in two health areas).

- Seven health area facilitators (Facilitadores de Area, FAs), who coordinate family planning and other maternal and child health care activities in the 18 non-priority health areas.

- Nine first level information, education, and communication (IEC) advisors (Facilitadores de $1^{\text {er }}$ Nivel, FIEC) who assist and coordinate community family planning and maternal and child health care IEC activities in priority areas.

The MSPAS is divided geographically into health areas. One health area usually manages the services in a department, the Guatemalan equivalent of a state. Health areas are divided in districts. Usually, at least one physician, one professional nurse, and one or more nurse auxiliaries that serve at the district headquarters staff a health center. In addition to the health center, a district has an average of five health posts (range of 1 to 12 posts) staffed by nurse auxiliaries. USAID/G has focused its activities in nine priority health areas with 
the poorest health indices and the highest concentration of indigenous populations; most of these are in the highlands.

The project was conducted in collaboration with the Guatemalan Association of Women Doctors (AGMM, for its Spanish acronym, Asociación Guatemalteca de Mujeres Médicas). This organization was selected because doctors who participated in the initial studies are AGMM affiliates, and they could take part either part-time or full-time in this project.

\section{OBJECTIVES}

The project's overall objective was to improve clients' ability to make an informed choice of contraceptive methods in public health service delivery institutions in Guatemala by scaling up the use of the balanced counseling strategy.

To achieve this goal, FRONTIERS conducted several activities:

1. Review, modify, and reproduce counseling aids, including the counseling algorithm and method-specific cards.

2. Review and develop materials to facilitate training of trainers (TOT) and use of the balanced counseling strategy, including slide shows, manuals, and a user's guide of counseling job aids.

3. Conduct a training program in three phases:

a. Phase I: National-level TOT, including 18 Calidad en Salud field staff, three central-level officers from MSPAS, and six from IGSS.

b. Phase II: Health area-level TOT, including 46 health area nurses (two per health area) and 73 IGSS service providers.

c. Phase III: District-level training of 268 nurses, 1,029 nurse auxiliaries at health centers and posts, and 127 community-based social workers.

4. Follow-up, supervision, and monitoring of phase II and III activities.

\section{ACTIVITIES}

The following activities were conducted during the project period:

\section{Review and reproduction of counseling aids and training materials}

In the two OR projects that tested the balanced counseling strategy in Guatemala, service providers and study participants made several recommendations for improving the counseling materials. The materials were adapted based on several suggestions: 
- Include family planning screening procedures. Staff members from Calidad en Salud recommended that the algorithm be adapted to screen all users of health facilities for their reproductive intentions and desire to use contraceptives. Based on this recommendation, four questions were included in the algorithm: 1) are you pregnant?; 2) if negative, would you like to have a child within the next two years?; 3 ) if negative, are you using contraceptives?; and 4) if negative, would you like to know more about contraceptive methods? The screening procedure is based on a previous study that used those questions to reduce barriers to providing family planning service. ${ }^{1}$ Part 1 of Appendix 1 presents a copy of the screening algorithm.

- Format. To make the format more user-friendly, the following recommendations were implemented: 1) a smaller version of the algorithm was produced, so that providers could use it on their desks during consultations; 2) a folded version was produced for easier storage; 3 ) clearer lines were drawn illustrating the alternative counseling paths, depending upon women's responses; and 4) logos and acknowledgements were incorporated.

- Content. During the two previous OR projects, service providers kept notes of cases that were not completely accounted for by the algorithm. Calidad en Salud and FRONTIERS staff members reviewed these cases and changed the counseling materials accordingly. For example, the algorithm did not provide clear instructions to the provider about what to advise women who stopped using a contraceptive method due to side effects or to women who did not use their method correctly. Similarly, the algorithm failed to instruct the provider to refer and to provide a temporary method when the desired method was not available at the health facility. Moreover, the original algorithm made no reference to other IEC materials, such as Calidad's flipchart and the method-specific leaflets. These references were included to make the counseling algorithm compatible with Calidad's IEC strategy.

- Cards. A few items that clients frequently asked about were included in the cards describing each method, such as eligibility criteria, failure rates, and information on how the method works. Also, at the request of USAID/G, an additional card describing the cervical mucus method was added to make cards consistent with brochures developed by Calidad en Salud.

The final version of the materials was adapted by Calidad en Salud staff to meet their program standards in terms of colors, layout, and format. This adaptation facilitated the nationwide scale-up and institutionalization of the strategy.

Appendix 1 includes the final versions of the counseling algorithm and the method-specific cards.

\footnotetext{
${ }^{1}$ Burkhart M., F. Mendez, and F. Lopez. 1999. How to Provide Direct, Safe, Barrier Free and High Quality Family Planning Services. Guatemala: Population Council. 


\section{Training materials and user's guide of counseling job aids}

A user's guide was developed to give service providers a step-by-step method of using the job aids and to explain the organization of the algorithm and the counseling procedure. The guide includes the following sections:

1. Screening for family planning needs (Part 1 of the revised algorithm)

2. The three phases of contraceptive decisionmaking
a. Assessment of reproductive health needs and reproductive intentions
b. Method choice
c. Post-selection support

The user's guide is included as Appendix 2.

During the TOT workshops, trainees received a kit that included the PowerPoint presentations needed to replicate the workshops and a workshop agenda. A variety of topics were included in the replicated workshops:

1. Training principles: how to train service providers to achieve behavioral change?

2. Supervising and monitoring the quality of counseling
a. How to supervise counseling sessions
b. Use of checklists
c. How to offer feedback to providers
d. How and how often to evaluate the quality of counseling practices

3. Questions and answers in counseling practices

a. Questions that clients frequently ask and how to respond to them

b. Questions that providers frequently ask and how to respond to them

\section{Training program}

The training process was designed in three phases, as follows:

\section{Phase I. Core TOT workshops}

The purpose of this initial workshop was to train Calidad en Salud field staff and selected $\mathrm{MOH}$ personnel as trainers of the balanced counseling strategy. Workshop contents included a review of counseling principles, role-playing exercises in the use of the balanced counseling methodology, and lessons on training trainers and how to conduct on-the-job supervision. The two and one-half day training program had the following schedule: 
Day 1

1. Welcome and presentation

2. Counseling concepts and elements (Calidad en Salud and FRONTIERS)

3. IEC materials developed by the Calidad en Salud program (Calidad en Salud)

4. Counseling in practice: three steps to decisionmaking (FRONTIERS)

5. Presentation of the counseling strategy (MSPAS, IGSS, and FRONTIERS)

Day 2

1. Counseling rehearsal: role playing (MSPAS, IGSS, and FRONTIERS)

2. Discussion: the role of the counselor

3. How to train health area personnel as counseling trainers

4. Practice and rehearsal (groups)

5. Rules and procedures of the in-service training and supervision

Day 3

1. Programming training at health areas

2. Presentation of programs

Two similar consecutive workshops were conducted. During these workshops, 47 trainers were trained to replicate the instruction workshop, among them 18 staff members of Calidad en Salud, 19 MSPAS, six IGSS and four NGO trainers.

Participants in the first workshop included 24 trainees and five trainers: 16 Calidad en Salud field staff members that supervise health centers and posts (two family planning regional advisors, seven ATRs and seven FAs), six IGSS central level officers, and two representatives from priority health areas. Trainees in the second workshop included two staff members from Calidad en Salud responsible for training community-based workers, nine first-level IEC advisors (FIEC), three central-level MSPAS officers, five representatives from priority health areas, and four additional participants from interested NGOs. A total of 23 participants and five trainers took part in the second TOT workshop, as shown in Table 1. 
Table 1. Number of participants in each workshop by affiliation, Phase I TOT

\begin{tabular}{|l|c|c|c|}
\hline & \multicolumn{3}{|c|}{$\begin{array}{c}\text { Phase I Training of Trainers } \\
\text { Workshops }\end{array}$} \\
\hline & $\begin{array}{c}\text { First } \\
\text { Workshop }\end{array}$ & $\begin{array}{c}\text { Second } \\
\text { Workshop }\end{array}$ & Total \\
\hline Calidad en Salud & & & \\
\hline Regional and national coordinators & 2 & 2 & 4 \\
\hline Rural technical advisors & 7 & & 7 \\
\hline Health area advisors (FAs) & 7 & & 7 \\
\hline Total & 16 & 2 & 18 \\
\hline & & & \\
\hline MOH personnel & & & \\
\hline Central level & & 3 & 3 \\
\hline Health areas & 2 & 5 & 7 \\
\hline Community-based trainers & & 9 & 9 \\
\hline Total & 2 & 17 & 19 \\
\hline & & & \\
\hline IGSS & 6 & & 6 \\
\hline & & & \\
\hline Other NGOs & & 4 & 4 \\
\hline & & & \\
\hline Total participants & $\mathbf{2 4}$ & $\mathbf{2 3}$ & $\mathbf{4 7}$ \\
\hline Number of trainers & $\mathbf{5}$ & $\mathbf{5}$ & $\mathbf{5}$ \\
\hline
\end{tabular}

The two and one-half day workshops took place in Quetzaltenango between May 12 and May 16, 2003. Irma Ramos, a Peruvian consultant who participated in the development of the counseling strategy in Peru and trained the staff in the two previous OR projects in Guatemala, conducted these initial workshops. Two AGMM staff members whom Ramos had trained previously (with six other AGMM staff members) during the week of May $5-11,2003$ also assisted with the workshop.

\section{Phase II. Training of nurses at health areas and IGSS hospitals}

Following the initial TOT, Calidad en Salud field staff conducted 23 additional TOT workshops, one per health area. The purpose of these workshops was to enable health district nurses to replicate the training workshop to educate nurse auxiliaries under their supervision in the use of the balanced counseling strategy.

The content of these workshops was similar to the initial TOT workshop. It included a review of counseling principles, use of the balanced counseling methodology, training of family planning counselors at their health districts, and how to conduct in-service supervised practice. The total duration of each workshop was also two and one-half days. One Calidad en Salud staff member, one or more AGMM supervisors, and one MSPAS central or area level counterpart conducted the training. 
The 47 trainers who received instruction during Phase I of the project trained a total of 165 new trainers. As a rule, two health area technical staff and one professional nurse or nurse auxiliary from each health district participated in Phase II of the program. Table 2 shows the number of personnel trained in this phase.

Table 2. Personnel trained during

Phase II of the training program by type of provider

\begin{tabular}{|l|c|}
\hline Type of service provider & Phase \\
\hline II \\
\hline Doctors & 2 \\
\hline Nurses & 45 \\
\hline Suxiliaries & 47 \\
\hline Rural Worker & 4 \\
\hline Administrative & 1 \\
\hline Other & 1 \\
\hline Total & 65 \\
\hline
\end{tabular}

Phase IIIa. Training of service providers at MSPAS

The purpose of Phase III training was to teach the use of the balanced counseling strategy to approximately 2,000 nurses, nurse auxiliaries, and social workers in the 284 health districts nationwide. Each health district was responsible for training their service providers. The primary responsibility for this training belonged to the 165 trainers who received training during Phase II. Health area nurses, Calidad en Salud staff (including four national supervisors and 14 regional supervisors), and four AGMM resource personnel provided support and supervision.

Service providers received their training in one day. It consisted of four topics:

1. Welcome and presentation

2. Counseling concepts and elements

3. Presentation of the counseling strategy

4. Counseling in practice: three steps to decision making

Table 3 below shows the number of workshops and the total number of participants in each health area. Project records show that, between July and November 2003, a total of 153 replicated workshops were conducted that included 2,275 MSPAS workers in 14 health areas. The number of trained providers increased steadily despite constraining factors, including a strike at MSPAS. 
Table 3. Number of participants and workshops per health area, MSPAS

\begin{tabular}{|l|c|c|}
\hline Health Area & Participants & Workshops \\
\hline Alta Verapaz & 305 & 13 \\
\hline Chiquimula & 163 & 12 \\
\hline Flores & 15 & 5 \\
\hline Guatemala & 748 & 33 \\
\hline Ixcán & 48 & 1 \\
\hline Izabal & 153 & 10 \\
\hline Jalapa & 113 & 8 \\
\hline Jutiapa & 137 & 10 \\
\hline Poptún & 59 & 4 \\
\hline Progreso & 94 & 9 \\
\hline Santa Rosa & 133 & 16 \\
\hline Sayaxché & 27 & 3 \\
\hline Suchitepequez & 110 & 12 \\
\hline Zacapa & 170 & 17 \\
\hline Total & $\mathbf{2 , 2 7 5}$ & $\mathbf{1 5 3}$ \\
\hline
\end{tabular}

Four supervisors received training to assess how effectively the workshops had been replicated according to standards set by the initial TOT workshop. Supervisors were nurses and educators with experience in training at MSPAS and who were in active service at the time the workshops were conducted.

To evaluate workshops, supervisors used a checklist that included 18 items pertaining to the trainers' performance, as follows:

1. Knew workshop objectives

2. Informed trainees about workshop objectives

3. Developed trust among participants

4. Used visual materials during sessions

5. Promoted active participation of trainees in activities

6. Adequately conducted group activities

7. Motivated trainees to provide high-quality services

8. Clearly explained the principles of balanced counseling

9. Clearly explained clearly the counseling algorithm

10. Clearly explained clearly the process to discard methods

11. Clearly explained clearly advantages and disadvantages of balanced counseling 12. Clearly explained the relationship between the GATHER ${ }^{2}$ and balanced counseling

\footnotetext{
${ }^{2}$ The GATHER strategy consists of the following six steps: Greet the client; Ask her reproductive intentions; Tell her about the method options; Help her to choose a method; Explain the method's proper use; and schedule a Return appointment (Rinehart, W., S. Rudy, and M. Drenan. 1998. GATHER Guide to Counseling, Population Reports, Series J, No. 48. Baltimore, Johns Hopkins University School of Public Health, Population Information Program, December.) 
13. Clearly explained the concept of RETEN (a training memory aid comprising Resultados, Entorno, Tiempo, Estilo, Novedad [Results, Environment, Time, Style, Innovation])

14. Each participant conducted at least three simulated counseling sessions

15. Each participant conducted at least five in-class rehearsals of counseling sessions

16. Each participant conducted at least five additional counseling sessions at medical facilities

17. Conducted workshop evaluation

18. Listened to opinions of participants

Each of the above items was rated on a five-point scale including very poorly, poorly, neither poor nor good, good, or very good. In addition, supervisors were expected to write comments and provide feedback to workshop coordinators.

Supervisors were able to evaluate 71 out of the 153 workshops conducted (46 percent coverage). In 40 additional workshops, supervisors had to intervene and participate as instructors because they felt that the trainer required assistance. Due to time and logistical constraints, supervisors were unable to attend 43 replicated workshops. Supervisors' reports show that 22 workshops ( 31 percent) were conducted with the highest adherence to preestablished standards, 43 workshop (61 percent) received a good ranking in most evaluation items, and only four workshops were viewed as not being adequately conducted.

The most common problem encountered during workshop implementation was that participants had limited opportunities to perform exercises and practice the counseling methodology. The workshop design expected participants to conduct at least five practices at medical facilities, with real clients. This was difficult to achieve due to time limitations. In several cases, it was costly and difficult for workshop participants to move to health facilities to conduct their practices.

According to supervisors' reports, workshop instructors used and explained the counseling methodology and counseling principles (quality of care) proficiently. After two or three replications, workshop coordinators were able to clearly explain the counseling framework. This is a highly positive outcome because workshop coordinators generally included MSPAS personnel (health district nurses) who have become knowledgeable of the counseling methodology and who may replicate workshops after the project ends. Table 4 shows the type of personnel that were trained during these workshops; a total of 208 doctors, 268 professional nurses and 1,029 nurse auxiliaries. Among community-based personnel, 43 community facilitators, 84 institutional facilitators and 59 rural social workers received training. 


\section{Table 4. Type of service providers trained during Phase III, MSPAS}

\begin{tabular}{|l|c|}
\hline Type of service provider & $\begin{array}{c}\text { Phase } \\
\text { III }\end{array}$ \\
\hline Doctors & 208 \\
\hline Nurses & 268 \\
\hline Auxiliaries & 1,029 \\
\hline Social worker & 44 \\
\hline Rural social worker & 59 \\
\hline Environmental health inspectors & 46 \\
\hline Community facilitator & 43 \\
\hline Institutional facilitator & 84 \\
\hline Mobile doctors & 39 \\
\hline Traditional attendants & 33 \\
\hline Administrative & 144 \\
\hline Other & 278 \\
\hline Total & $\mathbf{2 , 2 7 5}$ \\
\hline
\end{tabular}

\section{Phase IIIb: Training of service providers at IGSS}

IGSS family planning staff started their training program on July 1, 2003. All family planning service providers, including doctors, nurses, social workers, and other staff received their training directly. The number of trainees varied at each unit, depending on the number of individuals designated to provide family planning counseling. Training took place at each IGSS medical unit. Dr. Carlo Bonatto, coordinator of IGSS-related activities with the Calidad en Salud Project, coordinated the training at IGSS. Two trained educators, with ample experience working with the institution and who participated in the initial TOT, conducted field training and supervision.

There were two types of workshops. In the first type, only information about the balanced counseling strategy and the need to offer contraceptive services at all service delivery points was provided. This workshop was designed for administrative and decisionmaking staff at IGSS clinics. The second type of workshop offered information about the balanced counseling strategy and service providers received in-service training. Trainees rehearsed several practices and held actual counseling session with clients. Supervisors observed the counseling sessions using the project checklists and provided input and feedback to the trainee upon completion of the counseling session.

Table 5 shows that 126 participants attended the presentation about the counseling strategy and 73 service providers in the seven largest IGSS hospitals received training. These medical units provide 95 percent of family planning services offered by IGSS. 
Table 5. Number of participants and type of training: IGSS workshops

\begin{tabular}{|l|c|}
\hline Description of counseling strategy & $\begin{array}{c}\text { Number of } \\
\text { participants }\end{array}$ \\
\hline OB/Gyn Hospital & 29 \\
\hline Hospital Zona 6 & 30 \\
\hline Auxiliary Nurse School & 67 \\
\hline Total & $\mathbf{1 2 6}$ \\
\hline & \\
\hline In-service training & \\
\hline OB/Gyn Hospital & 20 \\
\hline Hospital Zona 6 & 14 \\
\hline Periférica Z. 5 & 6 \\
\hline Periférica Z. 11 & 4 \\
\hline Hospital Escuintla & 17 \\
\hline Hospital Tiquisate & 8 \\
\hline Hospital Santa Lucía & 4 \\
\hline Total & $\mathbf{7 3}$ \\
\hline
\end{tabular}

Table 6 shows the type of service providers and participants that attended each training session held at IGSS. Twenty-five auxiliary nurses and 26 social workers, the main staff that provide family planning counseling services, were trained during the in-service workshops. A large number of nurse auxiliaries who do not usually provide family planning counseling also participated in the counseling workshops. This may prompt more interest among IGSS staff to provide contraceptive information.

Table 6. Type of service providers trained: IGSS

\begin{tabular}{|l|c|c|c|}
\hline $\begin{array}{l}\text { Type of service } \\
\text { provider }\end{array}$ & $\begin{array}{l}\text { In-service } \\
\text { workshop }\end{array}$ & $\begin{array}{c}\text { Counseling } \\
\text { workshop }\end{array}$ & Total \\
\hline Doctor & 2 & 0 & 2 \\
\hline Nurse & 13 & 29 & 42 \\
\hline Auxiliary nurses & 25 & 97 & 122 \\
\hline Social worker & 26 & 0 & 26 \\
\hline Administrative & 0 & 0 & 0 \\
\hline Promoter & 0 & 0 & 0 \\
\hline Educator & 5 & 0 & 5 \\
\hline Other & 2 & 0 & 2 \\
\hline Non-IGSS & 0 & 13 & 13 \\
\hline Total & 73 & 113 & 182 \\
\hline
\end{tabular}




\section{FOLLOW-UP, MONITORING, AND SUPERVISION}

Project supervisors included 14 Calidad en Salud rural technical advisers (known as ATRs) and six trained supervisors from AGMM. The role of the supervisors was to ensure that trainees showed competence in using the balanced counseling strategy. They assisted health area nurses in implementing the training workshops and observed three to five rehearsed counseling sessions per participant. During the workshops, supervisors also trained health district nurses to conduct follow-up and supervision visits using a checklist, which is described below.

As a rule, health district nurses were expected to visit each of the trainees in their district two to five weeks later to ensure that they were actually using the counseling procedure. They also observed five non-rehearsed counseling sessions. Supervisors helped health district nurses conduct the follow-up and supervision visits. The four designated supervisors from AGMM visited selected health district nurses to ensure that they were using the counseling strategy and were effectively monitoring nurse auxiliaries under their supervision.

During follow-up visits, supervisors provided in-service training sessions using a checklist to verify if the provider asked or checked each of the following counseling aspects:

1. Asked if the client would like to space childbearing

2. Ruled out pregnancy

3. Asked if the clients has chosen a method

4. Displayed method cards

5. Asked if she would like to have more children in the future

6. Asked if she is breastfeeding

7. Asked if her partner collaborates with contraceptive method use

8. Determined if the client is ineligible to use a specific method

9. Described four characteristics of the eligible methods

10. Grouped the eligible methods according to the degree of effectiveness

11. Allowed client to choose a method

12. Reviewed contraindications of the selected method

13. Described mode of use

14. Described mechanisms of action

15. Described side effects and alarm signs

16. Made sure that the woman understood and was able to repeat the information provided

17. Provided instructions on follow-up

Trainers used the checklist to make sure that the service provider mentioned and properly followed each of the items above. 
Based on the above items, researchers developed a 100-point scale (percentage of items correctly applied) and classified providers in three categories: below 33 percent of items correctly applied, between 33 and 66 items, and above 66 items.

During training workshops, a total of 2,275 service providers trained at MSPAS and 73 providers received in-service training at IGSS. As part of the monitoring process, 500 of the providers who were trained received supervision visits: 448 (20 percent) at MSPAS and 52 (71 percent) at IGSS. Initially, this project expected to conduct at least two or three repeat visits to trainees; however, due to time and cost limitations, it was only possible to conduct 29 second visits.

Within MSPAS supervision visits were conducted in 15 priority health areas: Cobán, Chimaltenango, Chiquimula, Guatemala, Huehuetenango, Jalapa, Jutiapa, Quetzaltenango, Quiché, Rethalhuleu, San Marcos, Santa Rosa, Suchitepequez, Totonicapán, and Zacapa. Visits were made primarily to nurses (18 visits), nurse auxiliaries (383 visits), and community health promoters (43 visits).

On average, each provider conducted 3.5 observations per visit. Nurses required fewer observations to ensure that they were appropriately applying the counseling methodology ( 2.5 visits per nurse), as compared to nurse auxiliaries or other support personnel (3.7 observations per visit). Table 7 shows the scores achieved by area and by type of service provider. This table shows that most providers scored high (i.e. correctly applied the counseling methodology) in Cobán, Chimaltenango, Jalapa, Quetzaltenango, Rethalhuleu, and Suchitepequez. Training needed reinforcement in Guatemala City, Huehuetenango, Jutiapa, San Marcos, Santa Rosa and, to a lesser extent, Totonicapan, and Zacapa.

Table 7. Supervision scores (percent) by health area: MSPAS

\begin{tabular}{|l|c|c|c|c|c|c|}
\hline Area & $\begin{array}{c}\text { Incomplete } \\
\text { observation }\end{array}$ & Low & Medium & High & Total & $\begin{array}{c}\text { Number of } \\
\text { providers } \\
\text { observed }\end{array}$ \\
\hline Cobán & 11 & 0 & 0 & 89 & 100 & 9 \\
\hline Chimaltenango & 2 & 0 & 2 & 95 & 98 & 56 \\
\hline Chiquimula & 0 & 0 & 50 & 50 & 100 & 12 \\
\hline Guatemala & 16 & 13 & 25 & 46 & 100 & 68 \\
\hline Huehuetenango & 40 & 0 & 30 & 30 & 100 & 10 \\
\hline Jalapa & 0 & 10 & 10 & 80 & 100 & 10 \\
\hline Jutiapa & 0 & 0 & 33 & 67 & 100 & 3 \\
\hline Quetzaltenango & 0 & 0 & 18 & 80 & 100 & 49 \\
\hline Quiche & 12 & 14 & 18 & 56 & 100 & 66 \\
\hline Rethalhuleu & 0 & 0 & 0 & 100 & 100 & 57 \\
\hline San Marcos & 3 & 8 & 39 & 51 & 100 & 39 \\
\hline Santa Rosa & 33 & 33 & 0 & 33 & 100 & 3 \\
\hline Suchitepequez & 0 & 0 & 0 & 100 & 100 & 19 \\
\hline Totonicapan & 0 & 0 & 33 & 67 & 100 & 9 \\
\hline Zacapa & 3 & 0 & 31 & 66 & 100 & 32 \\
\hline Total & $\mathbf{7}$ & $\mathbf{5}$ & $\mathbf{1 8}$ & $\mathbf{7 0}$ & $\mathbf{1 0 0}$ & $\mathbf{4 4 2}$ \\
\hline
\end{tabular}


According to supervision reports, the most frequent provider error (about $25 \%$ of omissions identified) was failure to regularly offer family planning services to all clients who attended health facilities. Among providers who used the balanced counseling methodology, the most common error (approximately $15 \%$ of errors detected) was failure to explain method effectiveness. They also rarely asked about participation of the partner. Another common mistake was that providers failed to ensure that the client had correctly understood the information provided ( $8 \%$ of omissions identified).

Table 8 shows that 88 percent of service providers had an acceptable level of compliance with the counseling methodology (medium or high scores). Only 5 percent showed very low performance and 7 percent of the observations were incomplete or provided insufficient information.

Supervision reports showed that physicians were generally reluctant to use the methodology, the algorithm, and the counseling cards. They tend to rely on their own assessment of the client's characteristics and information needs. They rarely provide family planning counseling; this task was relegated to nurses and nurse auxiliaries. However, those physicians who do inform women about contraceptives usually implement the methodology well. Doctors, especially female doctors, who used the counseling methodology did so very effectively and made very positive comments about its usefulness in informing women about contraceptives.

Nurses and nurse auxiliaries were most likely to adhere to the procedures specified by the counseling methodology_-90 and 92 percent, respectively, show high or medium levels of compliance. Only three-quarters of them, however, achieved the highest supervision scores. Fifty-six percent of other trained personnel, such as rural technicians, social workers, rural health promoters, and health educators, obtained the highest scores, and 17 percent more achieved medium scores.

In addition to the errors and omissions mentioned above, the main problem observed during supervision is the limited knowledge that service providers have of contraceptive technology. Most providers have been trained about this technology, but they rarely inform women about contraceptive options, and they tend to forget what they learned in one- or two-day workshops.

Table 8. Supervision scores (percent) by health area: MSPAS

\begin{tabular}{|l|c|c|c|c|c|c|c|}
\hline & & & \multicolumn{3}{|c|}{ Supervision scores } & \\
\hline Occupation & Cases & Avg. Obs & Incomplete & Low & Medium & High & Total \\
\hline Doctor & 44 & 3 & 26 & 16 & 14 & 44 & 100 \\
\hline Nurse auxiliary & 322 & 4 & 3 & 4 & 19 & 74 & 100 \\
\hline Nurse & 63 & 4 & 5 & 5 & 16 & 74 & 100 \\
\hline Other & 19 & 4 & 22 & 0 & 17 & 56 & 100 \\
\hline Total & $\mathbf{4 4 8}$ & $\mathbf{4}$ & $\mathbf{7}$ & $\mathbf{5}$ & $\mathbf{1 8}$ & $\mathbf{7 0}$ & $\mathbf{1 0 0}$ \\
\hline
\end{tabular}

Service providers at IGSS showed higher compliance scores than their MSPAS counterparts. In the case of IGSS, family planning services are rarely provided outside of 
the three main hospitals in Guatemala City. One major accomplishment of this project was training personnel at all eligible medical units (including smaller medical offices, consultorios) to offer information and services.

Among the 52 IGSS service providers who received training, 30 were social workers and 10 were educators. After the training, they will assume responsibility for systematically providing information to clients who attend their facilities. Among the providers who were observed, 56 percent showed the highest compliance scores according to project supervisors, and 35 percent more demonstrated adequate performance. Only 10 percent of the providers (primarily nurses who were reluctant to provide family planning or other services) showed poor performance. Both IGSS and MSPAS providers frequently missed the same items or issues - lack of systematic provision of family planning services, failure to explain method effectiveness, and failure to properly ask about partner participation. In the case of IGSS, it was observed that some providers, especially doctors, avoid using the method-specific cards, although they read them without showing them to clients. 


\section{PROBLEMS AND SOLUTIONS}

Several problems were encountered during the reporting period. FRONTIERS and Calidad en Salud implemented a variety of solutions.

\section{Turnover at the Ministry of Health}

In December 2002, the Minister of Health and the director of the Reproductive Health Program left their positions, and the new health minister requested that training activities be postponed until they could be reviewed. As a consequence, the training workshops scheduled for February 2003 were postponed until May 2003. Although the new head of the Reproductive Health Program, a former executive director of the Asociación ProBienestar de la Familia [Family Welfare Association, known as APROFAM], has been supportive of the project, he has been reluctant to schedule any training without direct orders from the minister's office. To solve this situation, FRONTIERS and Calidad en Salud decided in April 2003 to program the initial training as a Calidad-exclusive training activity that would not require ministerial approval. MSPAS and IGSS personnel were invited to the workshops, which they chose to attend.

\section{Loss of project staff}

As a consequence of project activities being postponed and uncertainty about when the project would start, the proposed project staff, who had implemented the previous two OR projects, accepted other employment. To solve this problem, training for the two initial workshops was conducted by Irma Ramos, the Peruvian consultant who participated in developing the counseling strategy in Peru and who trained the staff in the two previous OR projects in Guatemala.

\section{Inter-institutional coordination}

Inter-institutional coordination between Calidad en Salud and FRONTIERS has been very active and collegial. USAID/G has praised this collaboration and views it as being exemplary. Inter-institutional coordination has required a substantial amount of interaction between Calidad en Salud and FRONTIERS. This interaction has been a key factor in the successful nationwide scale-up of the counseling strategy. 


\section{APPENDIX 1. COUNSELING ALGORITHM AND METHOD- SPECIFIC CARDS}




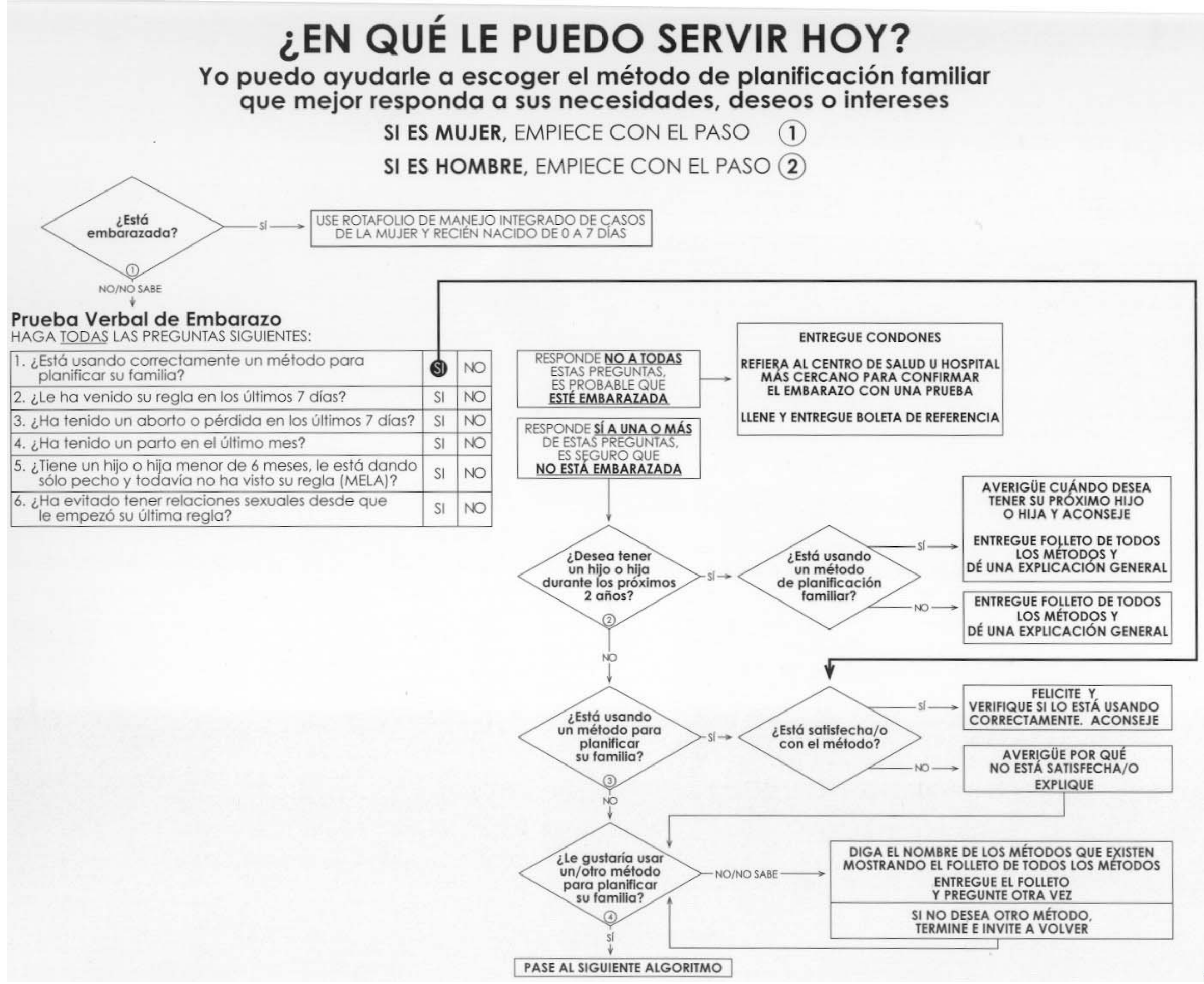




\section{MÉTODOS DE PLANIFICACIÓN FAMILIAR}

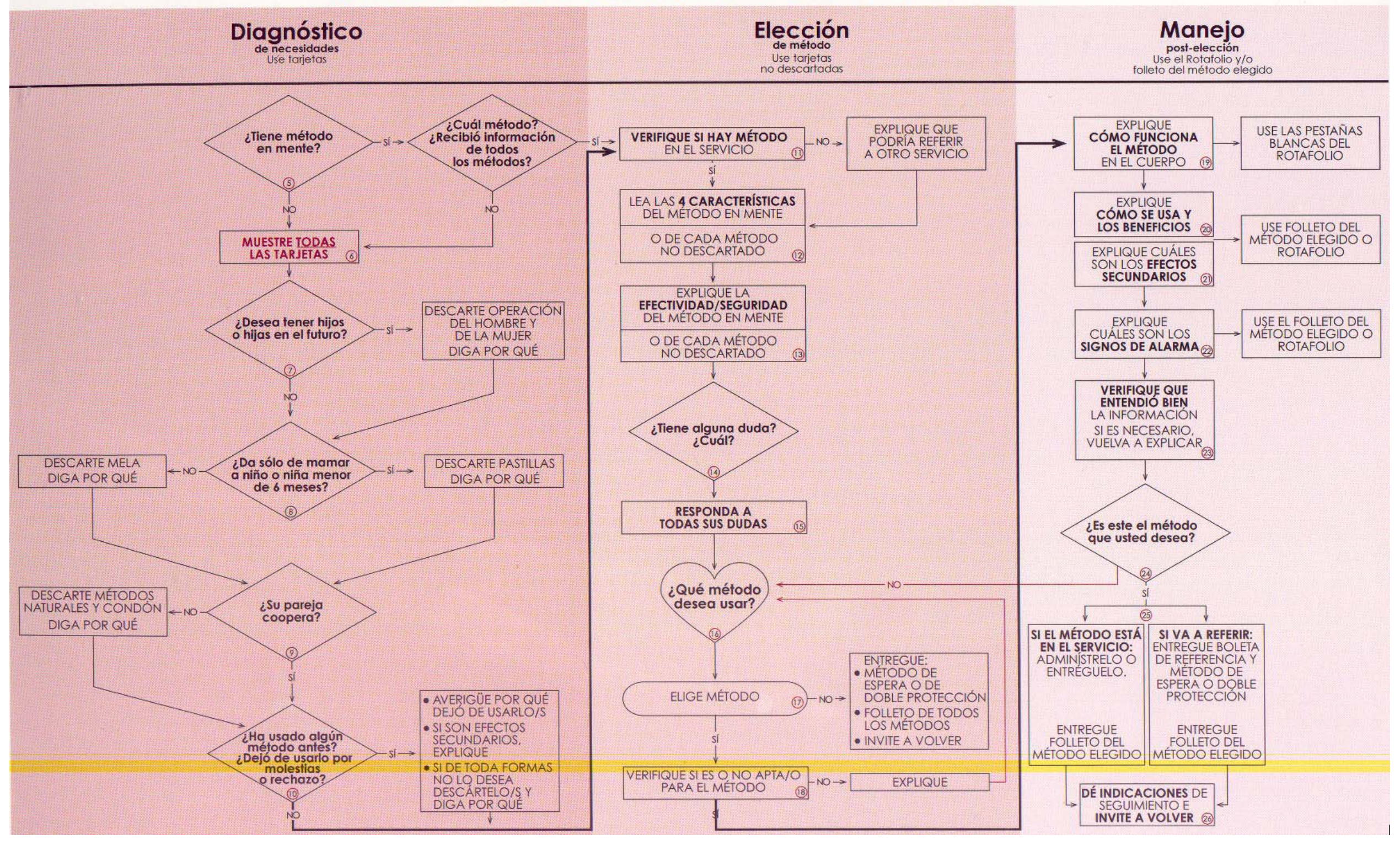


A

\section{LA T DE $\underset{\text { (DIU) }}{C O B R E}$}

1. El personal de salud la coloca dentro de la matriz de la mujer. Está hecha de plástico y cobre.

2. Dura hasta 10 años. Sólo tiene que ir al servicio de salud una vez al año para control.

3. Cuando la mujer desea quedar embarazada sólo va al servicio de salud para que se la quiten.

4. Es normal que en los primeros meses de uso, algunas mujeres tengan aumento en el sangrado durante la regla y/o cólico menstrual.

ESTE MÉTODO NO EVITA LAS INFECCIONES DE TRANSMISIÓN SEXUAL NI VIH/SIDA

A

\section{EL COLLAR}

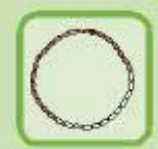

1. Sirve de guía a las parejas para saber qué días no deben tener relaciones sexuales para evitar un embarazo

2. Requiere la colaboración de la pareja.

3. La mujer debe tener su regla o menstruación cada 26 a 32 dias.

ESTE MÉTODO NO EVITA LAS INFECCIONES DE TRANSMISIÓN SEXUAL NI VIH/SIDA

\section{PREGUNTE:}

B

- zilene sangrado de la vagina que no sea de menstruación?

- zitiene o ha tenido infecciones o flujo vaginala

- ¿Ho tenido recientemente un aborto o parto infectado?

- ¿tiliene conormalidades uterinas o tumores benignos?

- ztrlene usted o su pareja varias parejas sexu cles?

ASEGÚRESE QUE LA MUJUR NO EST A EMBARAZADA O CON SOSPECHA DE EMBARAZO

\section{ASEGÚRESE CON UN EXÁMEN QUE:}

- NO TIENEEL CUELLO DE MATRIZ CERRADO O RIGIDO

- No TIENE ANORMALIOADES O TUMORES UTERINOS

SI RESTONDE SI A IODAS LAS PREGUNTAS Y COMPRUEBA CON EL EXÁMEN QUE NO IIENE NINGUNA DE LOS ASPECIOS MENCIONADOS, QUIERE DECIR QUE ES UN METODO APROPIADO PARA LA MUJER

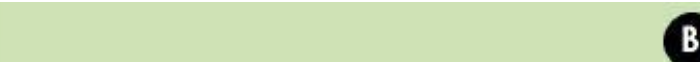

PREGUNTE:

- ¿̇Sus ciclos menstruales son cortos. De 25 días o menos?

- ¿3us ciclos menstruales son largos, con más de 32 días?

- ¿Su pareja está de acuerdo en evitar relaciones sexuales los días que puede quedar embarazada?

- SI ES UNA MUJER POSPARTO: s.Ha tenido por lo menos 3 ciclos menstruales regulares (entre 26 a 32 días)?

- áUn embarazo puede ser peligroso para usted y/o su hijo o hija?

RESPONDE SI A CUALQUIERA DE LAS PREGUNTAS, ES UN METODO NO APROPIADO PARA LA MUJER
A

\section{EL CONDÓN}

1. Es una bolsita resistente hecha de un material elástico que se llama látex que se coloca en el pene del hombre.

2. Es el único método que protege a usted y su pareja de Infecciones de Transmisión Sexual y VIH/SIDA.

3. Se coloca en el pene del hombre cuando ya está erecto (parado) antes de meterlo en la vagina de la mujer.

4. Se usa uno nuevo para cada vez que acaba.

ESTE MÉTODO ES EL ÚNICO QUE EVITA LAS INFECCIONES DE TRANSMISION SEXUAL Y VIH/SIDA

\section{PREGUNTE:}

- iel embarazo puede ser pelgraso para la salud de su parejar

- sustedo su parejascri alérgiocs al material con que se fabrica el condór pátexp

\section{RESPONDE SI A CUALQUIERA DE LAS PREGUNIAS,} ES UN METODO NO APROPIADO PARA EL HOMBRE O LA MUJER 


\section{A LA INYECCIÓN}

1. Es una inyección que se pone en la cadera o el brazo cada 3 meses.

2. Cuando la mujer desee quedar embarazada, deja de ponérsela. Pero puede pasar hasta un año antes de quedar embarazada otra vez.

3. Es normal que en los primeros meses de uso, algunas mujeres dejen de ver su menstruación, sentir dolor de cabeza, mareos y/o náuseas. Generalmente desaparecen.

4. Después de seis semanas del parto, la pueden usar las mujeres que están dando pecho.

ESTE MÉTODO NO EVITA LAS INFECCIONES 1 de 200 DE TRANSMISIÓN SEXUAL NIVIH/SIDA

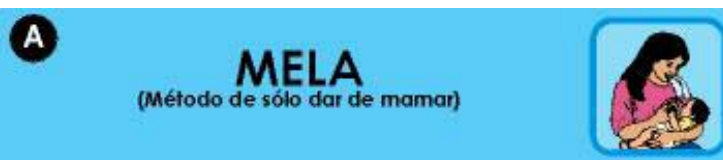

Es un método que funciona sólo si:

1. La mujer no ha visto su regla o menstruación después del parto.

2. La mujer da sólo pecho cada vez que el nifno o la niña quiera mamar de día y de noche.

3. El niño o niña tiene menos de 6 meses de edad.

ESTE MÉTODO NO EVITA LAS INFECCIONES DE TRANSMISIÓN SEXUAL NI VIH/SIDA
PREGUNTE:

- zliene sangrado de la vagina que no sea de menstruación?

- zLe molestaria mucho tener cambios en su menstruación. especialmente no ver su menstruación?

- ¿Ha terido o tiene cáncer de mama? ASEGÚRESE QUE LA MUJER NO ESTÁ EMBARAZADAO
CONSOSPECHA DE EMBARAZO

RESPONDE SI A ALGUNA DE LAS PREGUNTAS, ES UN MÉTODO NO APROPIADO PARA LA MUJER

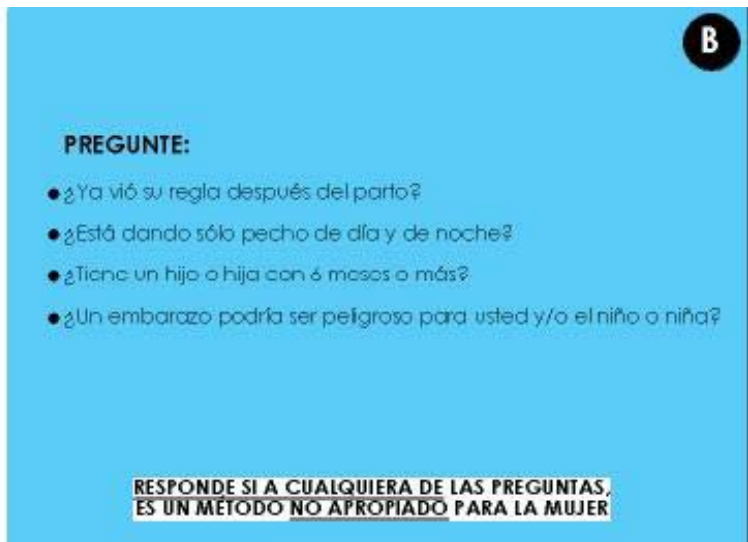

A

\section{LA OPERACIÓN DE LA MUJER}

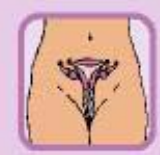

1. Es una operación para la mujer que ya no desea tener más hijos o hijas. Es para siempre.

2. Es una operación sencilla y muy segura que dura menos de 20 minutos.

3. Las relaciones sexuales de la pareja siguen igualy la mujer sigue viendo su regla.

4. La mujer puede regresar a su casa el mismo dia, entre 2 y 6 horas después de la operación.

ESTE MÉTODO NO EVITA LAS INFECCIONES DE TRANSMISIÓN SEXUAL NI VIH/SIDA 

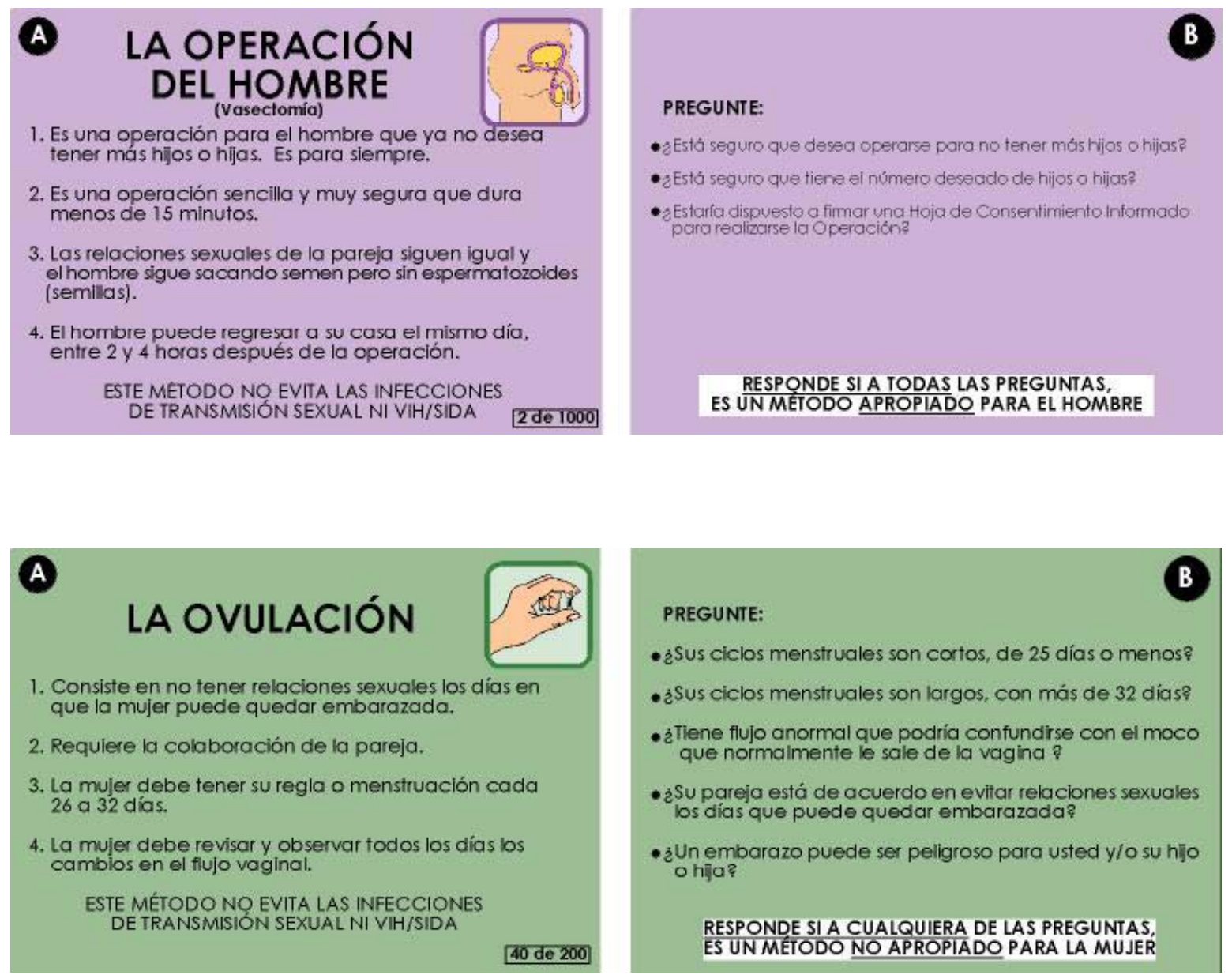

A

\section{LA PASTILLA}

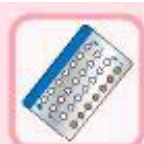

1. Es una pastilla que la mujer toma todos los días, a la misma hora.

2. Cuando la mujer desea quedar embarazada, sólo deja de tomarlas al terminar el sobre.

3. Es normal que en los primeros meses de uso, algunas mujeres sientan náuseas, mareos y/o vómitos. Generalmente desaparecen.

4. Si está dando de mamar, puede empezar a tomarla 6 meses después del parto.

ESTE MÉTODO NO EVITA LAS INFECCIONES DE TRANSMISIÓN SEXUAL NI VIH/SIDA

PREGUNTE:

- 2́Tiene sangrado de la vagina que no sea de menstruación?

- ítiene alguna enfermedad del higado (ICTERICIA)?

- 2Tiene más de 35 años y fuma más de 15 cigaros al díá

- EHa tendo alguna enfermedad del corazón, infarto, presón alta, dificil coagulación de la sangre o diabetes por 20 años o más?

- ¿H Ha terido o tlene cóncer de mama?

- ¿Cree que se le podría olvidar tomar la pastilla todos los díasa

- Étiene un nirno o niña menor de sels meses y todavía le está dando de mamar

ASEGÚRESE QUE LA MUJER NO ESTA EMBARARZADA O CON SOSPECHA DE EMBARAZO

SI RESPONDE SI A IODAS LAS PREGUNTAS, QUIERE DECIR QUE ES UN METODO APROPIADO PARA LA MUJER 


\begin{tabular}{|c|c|c|}
\hline \multicolumn{3}{|l|}{$\begin{array}{l}\text { Prueba verbal de embarazo } \\
\text { HAGA TODAS LAS PREGUNTAS SIGUIENTES: }\end{array}$} \\
\hline 1. 2Lle ha venido su regla en los últimos 7 dias? & Si & No \\
\hline 2. ¿̇Ha tenido un aborto o pérdida en los últimos 7 dias? & $\mathrm{Si}$ & No \\
\hline 3. átla tenido un parto en el último mes? & $\mathrm{Si}$ & No \\
\hline $\begin{array}{l}\text { 4. ¿̇iene un hijo o hija menor de } 6 \text { meses, le está dando } \\
\text { sólo pecho y todavía no ha visto su regla (MELA)? }\end{array}$ & Si & No \\
\hline $\begin{array}{l}\text { 5. âHa evitado tener relaciones sexuales desde que } \\
\text { le empezó su última regla? }\end{array}$ & $\mathrm{Si}$ & No \\
\hline
\end{tabular}

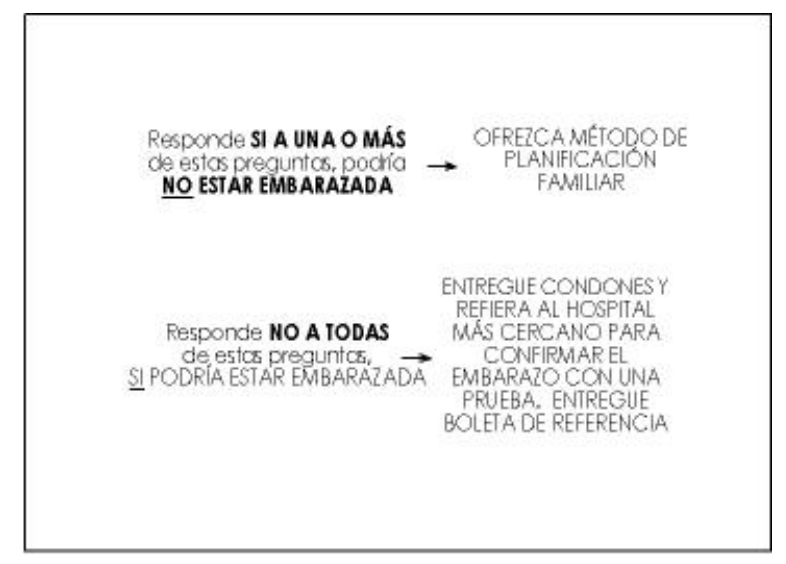




\section{APPENDIX 2 . USER'S GUIDE FOR THE ALGORITHM AND CARDS}


Instrucciones generales:

- El Algoritmo de Consejería Balanceada en Planificación Familiar es una herramienta de ayuda al trabajador/a de salud para dar consejería equilibrada sobre todos los métodos de planificación familiar.

- En el Algoritmo los $>$ indican preguntas que hace el trabajador/a de salud. Los $\square$ indican acciones o decisiones que toma el trabajador/a de salud.

- Los pasos están numerados, del 1 al 26, encerrados en círculos. Hay círculos corintos y negros.

- Si la consejería se la da a una mujer y/o pareja, empiece con el paso 1 y continúe con todos los círculos (corintos y negros).

- Si es a un hombre solo, sugiérale que llegue acompañado de su pareja. Empiece con el paso 2 y continúe con los círculos corintos.

- El Algoritmo consta de dos partes:

\section{Parte 1 (¿EN QUÉ LE PUEDO SERVIR HOY?)}

Se utiliza para ofertar el servicio de planificación a cualquier hombre y/o mujer que llegue al servicio de salud, independientemente del motivo. En esta parte se define si la persona desea y/o es apta o no para utilizar un método para planificar la familia.

Requiere el uso de la tarjeta de Prueba Verbal de Embarazo, la cual está incluida en este Algoritmo.

\section{Parte 2 (MÉTODOS DE PLANIFICACIÓN FAMILIAR)}

Sirve para dar consejería a la persona que YA SE DECIDIÓ Y ES APTA para utilizar un método de planificación familiar. Está dividida en 3 secciones:
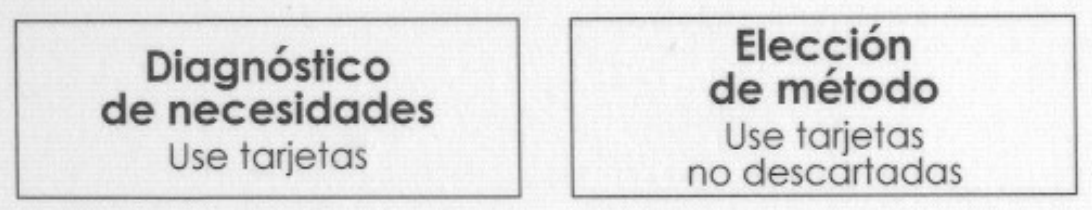

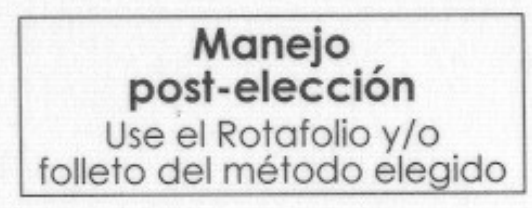

- El Diagnóstico de necesidades y la Elección de método requiere del uso de 9 tarjetas: Una de cada método de planificación familiar:

MELA, Ovulación, Collar, Condón, Pastilla, Inyección, T de Cobre, Operación del Hombre y Operación de la Mujer.

- El Manejo post-elección requiere el uso del folleto del método elegido y/o del rotafolio.

- Para apoyar las explicaciones que debe dar, puede usar:

Cuadrifoliar de Todos los Métodos, muestrario de métodos, el Rotafolio de Planificación Familiar, el trifoliar de cada uno de los métodos, según se indica.

- Descartar significa sacar la/s tarjeta/s del método/s que se menciona/n en el recuadro. Cuando descarte un método, lea a la persona los mensajes que aparecen resaltados 0 en negritas. Déjela/s a un lado, fuera del marco visual suyo y de la persona. 


\section{Instrucciones Específicas:}

\section{Parte 1 (¿EN QUÉ LE PUEDO SERVIR HOY?)}

Dé una bienvenida cordial, atiéndala/o con amabilidad y respeto.

Si es mujer, empiece con el paso (1)

Si es hombre, empiece con el paso (2)

(1) Pregúntele a la mujer si está embarazada.

Dice Sí: Use el Rotafolio de Manejo Integrado de Casos de la Mujer y Recién Nacido de 0 a 7 días. Dice NO O NO SABE: Haga la Prueba Verbal de Embarazo

PRUEBA VERBAL DE EMBARAZO

Dice Sí a la pregunta 1: (¿Está usando correctamente un método para planificar su familia?): pase hacia donde le indica la flecha. Pregunte si está satisfecha con el método que usa. Continúe según la respuesta de la persona.

Dice NO a las preguntas 1, 2, 3, 4, 5, 6: es probable que esté embarazada. Entregue condones y refiera al centro de salud u hospital más cercano para confirmar el embarazo con una prueba. Llene y entregue boleta de referencia.

Dice Sí a una o más de las preguntas $2,3,4,5,6$ : es seguro que NO está embarazada. Continúe con el paso 2

(2) Pregúntele a la persona si desea tener un hijo o hija durante los próximos 2 años.

Dice Sí: Pregúntele si está usando un método para planificar su familia

Dice Sí: Averigüe cuándo desea tener su próximo hijo o hija y aconseje. Entregue folleto de todos los métodos y dé una explicación general.

Dice NO: Entregue folleto de todos los métodos y dé una explicación general. Dice NO: Continúe con el paso 3

(3) Pregúntele a la persona si está usando un método para planificar su familia.

Dice Sí: Pregúntele si está satisfecha/o con el método que usa

Dice Sí: Felicítela/o. Verifique si lo está usando correctamente. Aconseje.

Dice NO: Averigüe por qué no está satisfecha/o con el método. Explique.

Dice NO: Continúe con el paso 4 Continúe con el paso 4

(4) Pregúntele a la persona si le gustaría usar un/otro método para planificar su familia.

Dice sí: Pase al siguiente algoritmo. Continúe con el paso 5

Dice NO O NOSABE: Diga el nombre de los métodos que existen mostrando el folleto de todos los métodos. Entregue el folleto y pregunte otra vez si le gustaría usar otro método (paso 4).

Si después de preguntar nuevamente dice que NO desea un/otro método, termine e invite a volver.

Si después de preguntar nuevamente dice que sí desea un/otro método, pase al siguiente algoritmo para que escoja un método. Continúe con el paso 5 


\section{Parte 2 (MÉTODOS DE PLANIFICACIÓN FAMILIAR)}

Felicite a la persona por la decisión de planificar e inicie el llenado de la historia clínica. Ponga atención en la edad, datos obstétricos y situación marital.

(5) Pregúntele a la persona si tiene algún método en mente.

Dice Sí: Pregunte cuál método. Verifique si recibió información sobre todos los demás métodos.

Dice Sí: Continúe con el paso 11 y luego como se indica.

Dice NO: Continúe con el paso 6

Dice NO: Continúe con el paso 6

6) Si es mujer: Muestre TODAS las tarjetas con el lado "A" viendo hacia la persona. Dígale que ésas son las opciones de métodos que tiene para planificar su familia. Continúe con el paso 7 Si es hombre: Muestre las tarjetas con el lado "A" de Operación del Hombre y Condón viendo hacia la persona y digale que ésas son las opciones de métodos que tiene para planificar su familia. Continúe con el paso 7

(7) Pregunte si la persona desea tener hijos o hijas en el futuro.

Dice Si: Descarte la Operación del Hombre y la Operación de la Mujer y diga por qué.

Si es mujer: Continúe con el paso 8

Si es hombre: Continúe con el paso 10

Dice NO y es mujer: Continúe con el paso 8

Dice NO y es hombre: Continúe con el paso 10

(8) Pregunte a la mujer si da sólo pecho a un niño o niña menor de 6 meses y todavia no ha visto su regla. Dice Sí: Descarte Pastillas y diga por qué. Continúe con el paso 9

Dice NO: Descarte MELA y diga por qué. Continúe con el paso 9

(9) Pregunte si su pareja coopera.

Dice Sl: Continúe con el paso 10

Dice NO: Descarte los métodos naturales (Ovulación y Collar) y el Condón que requieren colaboración de la pareja. Continúe con el paso 10

(10) Pregunte si ha usado algún método antes y si dejó de usarlo por molestias o rechazo.

Dice Sí: Averigüe por qué dejó de usarlo/s. Explique si son efectos secundarios, aclare mitos e ideas equivocadas y, si de todas formas no quiere el método del que habla, descártelo/s, diga por qué. Continúe con el paso 11

Dice NO: Continúe con el paso 11

(11) Fijese en las tarjetas que le quedan (métodos NO descartados) y analice si hay ése o esos métodos en el servicio. Explíquele cual/es métodos puede administrar o entregar en el servicio y cual/es no está/n disponible/s en el servicio pero podría referir. Continúe con el pasol2

(12) Lea las 4 características del método en mente o de cada método no descartadollado " $\mathbf{A}$ " de la tarjeta, interactuando con la persona para que no pierda interés. Si tiene un muestrario, muestre los métodos y permítale que los toque. Continúe con el paso 13

(13) Explique la efectividad o seguridad del método en mente o de cada método no descartado.

En la esquina inferior derecha del lado "A" aparece la efectividad o seguridad del método medido en número de embarazos en un año por cada 200 personas que lo usan, a excepción de la Operación del Hombre que está medido por cada 1000 hombres operados. Si hay varios métodos explíquele a la persona cuál es el más y el menos seguro. Continúe con el paso 14

(14)Pregunte a la persona si tiene dudas o preguntas acerca de las explicaciones ofrecidas y cuáles. Continúe con el paso 15

(15) Responda todas las dudas o preguntas que la persona tenga. Continúe con el paso 16

(16) Mostrando las tarjetas NO descartadas pregúntele a la persona qué método desea usar. Deje un momento para que la persona piense y elija el método que le gustaría usar o el que más le conviene. Continúe con el paso 17 
(17) Verifique si la persona elige un método para planificar su familia.

Dice Si: Deje a la vista solamente la tarjeta con el método elegido. Continúe con el paso 18

Dice NO: Entregue método de espera o de doble protección, un folleto de Todos los Métodos e invite a volver, Termine

(18) Para verificar si la persona es o no apta/o para utilizar el método, use el lado "B" de la tarjeta del método elegido. Hágale todas las preguntas que ahí aparecen y si la tarjeta lo menciona, verifique con el examen físico lo que ahi se indica. Lea lo que dice en el cuadro blanco para decidir si la persona es o no apta para usar el método.

NO es apta/o: Explíquele por qué no puede usar el método elegido y regrese al paso 16.

Vuelva a poner sobre la mesa las tarjetas de los métodos que estaban en el momento en que decidió qué método usar (paso 16)

Sles apta/o: Continúe con el paso 19

(19) Explique cómo funciona el método elegido en el cuerpo. Para esta explicación puede usar las pestañas blancas del rotafolio de Planificación Familiar, donde encontrará:

- El aparato reproductor masculino

- El aparato reproductor femenino

- El ciclo menstrual

- Cómo ocurre un embarazo

Continúe con el paso 20

(20) Explique cómo se usa el método y sus beneficios. Use el folleto del método elegido o el rotafolio para dar esta explicación. Continúe con el paso 21

(21) Explique cuáles son los efectos secundarios del método elegido. Use el folleto del método elegidc o el rotafolio para dar esta explicación. Diga que los efectos secundarios son molestias que dan algunos métodos, en lo que el cuerpo se va acostumbrando, que son normales. Casi siempre son pasajeras y no representan un riesgo para la salud. Continúe con el paso 22

(22) Explique cuáles son los signos de alarma o complicaciones por los que debe volver al servicio. En la contraportada (parte de atrás) el folleto enumera los signos de alarma por los que la personc debe volver. En el Rotafolio de Planificación Familiar hay dibujos de cada signo de alarma. Use cualquiera de los dos para dar esta explicación. Continúe con el paso 23

(23) Verifique que la persona entendió bien la explicación preguntándole cómo se usa el método, que molestias podría tener, cuándo debe regresar rápido al servicio, etc. Si es necesario, vuelva a explica Continúe con el paso 24

(24) Siempre pregunte si ése es el método que la persona quiere usar para verificar que, después de haber oído las explicaciones sobre el método elegido, mantiene su elección.

Dice Sí: Continúe con el paso 25

Dice NO: Regrese al paso 16. Vuelva a poner sobre la mesa las tarjetas de los métodos que estabaı en el momento en que decidió qué método usar. Continúe como se indica.

(25) Si el método elegido:

Está disponible en el servicio: Administrelo o entréguelo. Entregue el folleto del método elegido. Continúe con el paso 26

NO está disponible en el servicio: Llene y dele una Boleta de Referencia. Refiera al servicio apropiad y entregue método de espera o doble protección y explíquele como se usa. Entregue folleto del método elegido y del método de espera. Continúe con el paso 26

(26) Dígale a la persona cuándo debe volver para controles o para recibir más métodos. Es convenient anotarle la fecha de la próxima cita en un carnet. Siempre invítela/o a volver en cualquier moment que lo desee. Despídase con amabilidad. 


\section{APPENDIX 3: TRAINING MATERIALS}




\section{Sesión $N^{0} 2$}

\section{GESTIÓN DE LA CAPACITACIÓN}

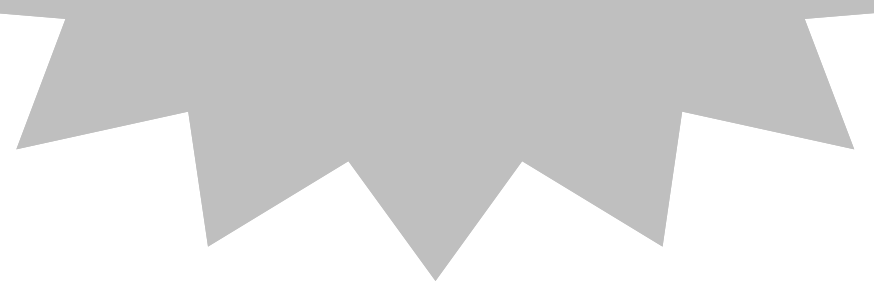

\section{¿COMO APRENDEN LOS ADULTOS?}

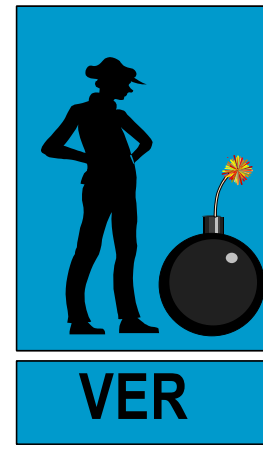

CAPTACIÓN

DEL

MENSAJE

EXTERNO

PERCEPCIÓN SENSORIAL

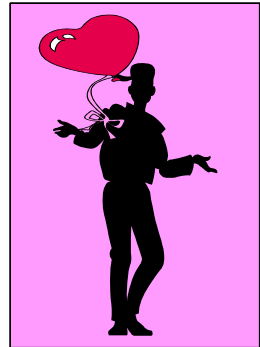

\section{SENTIR}

DESDE LA

EXPERIENCIA

HISTORICA

REACCIÓN

EMOCIONAL
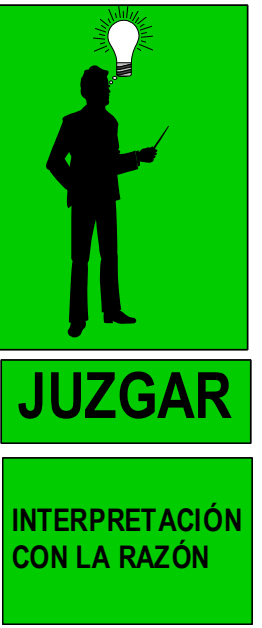

ANALISIS RACIONAL

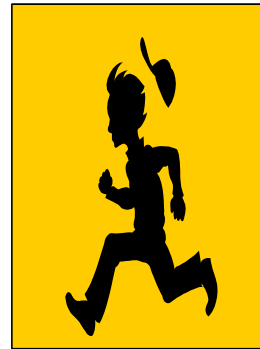

ACTUAR

IMPLICANCIA DE DECISIÓN Y ACCCIÓN

PROPUESTA DECISIONAL 


\section{GESTIÓN DE PROGRAMAS DE CAPACITACION}

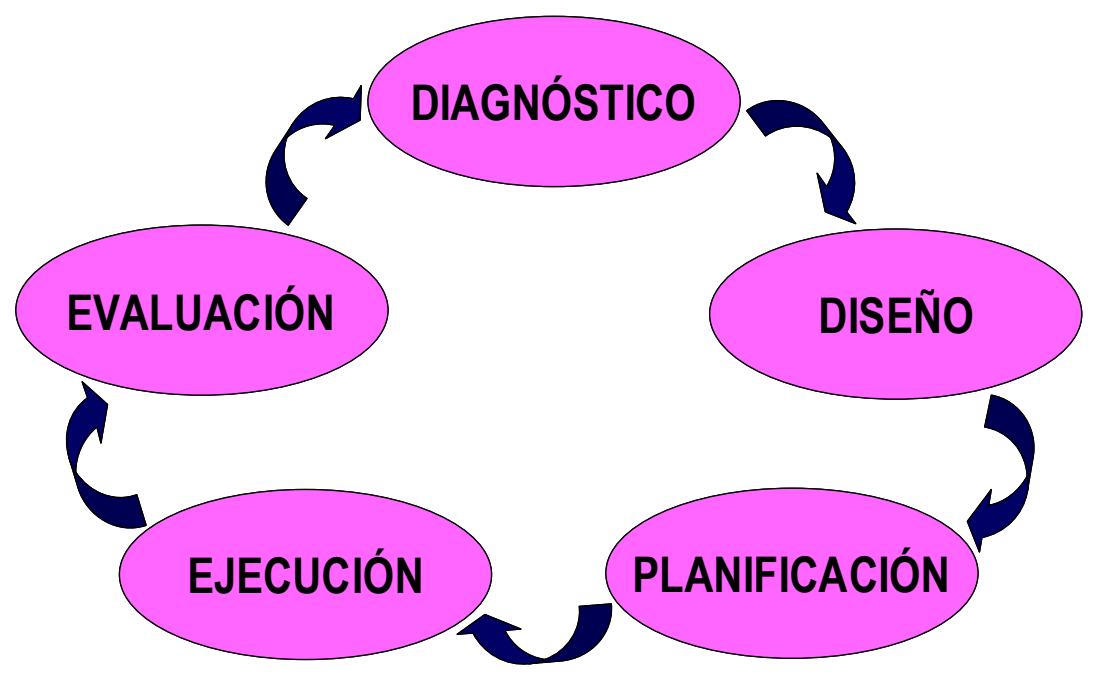

GESTIÓN DE PROGRAMAS DE CAPACITACION

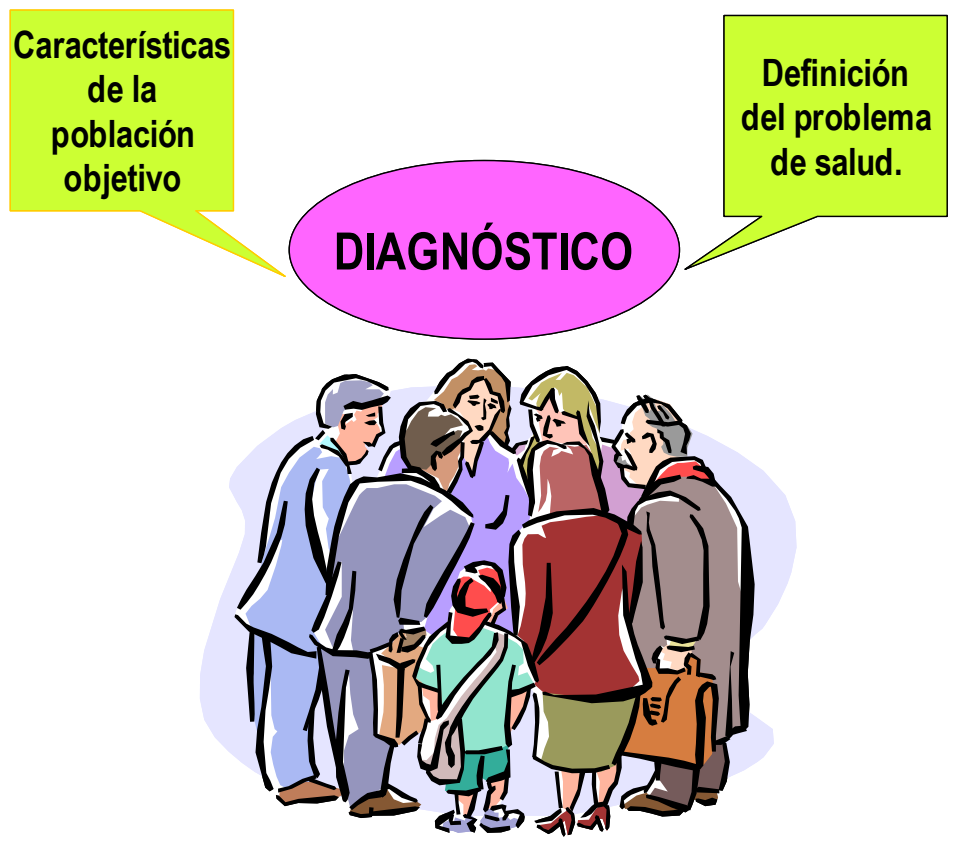




\section{GESTIÓN DE PROGRAMAS DE CAPACITACION}
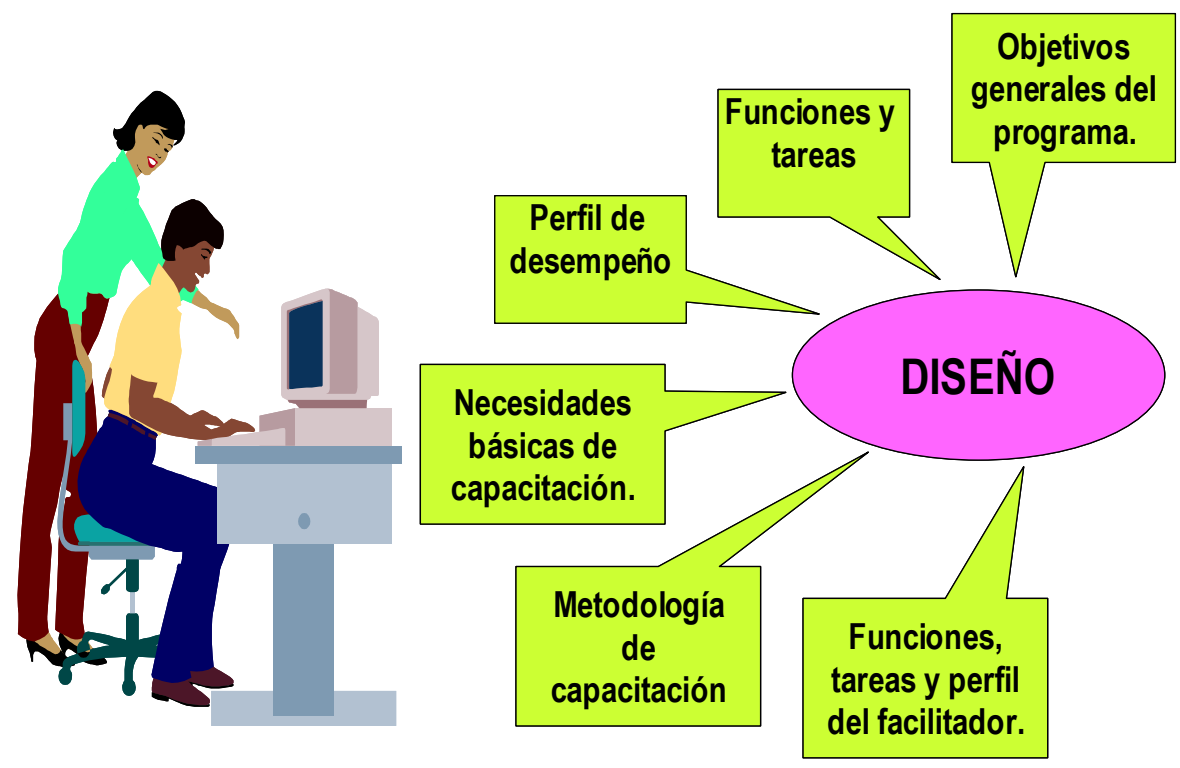

\section{GESTIÓN DE PROGRAMAS DE CAPACITACION}

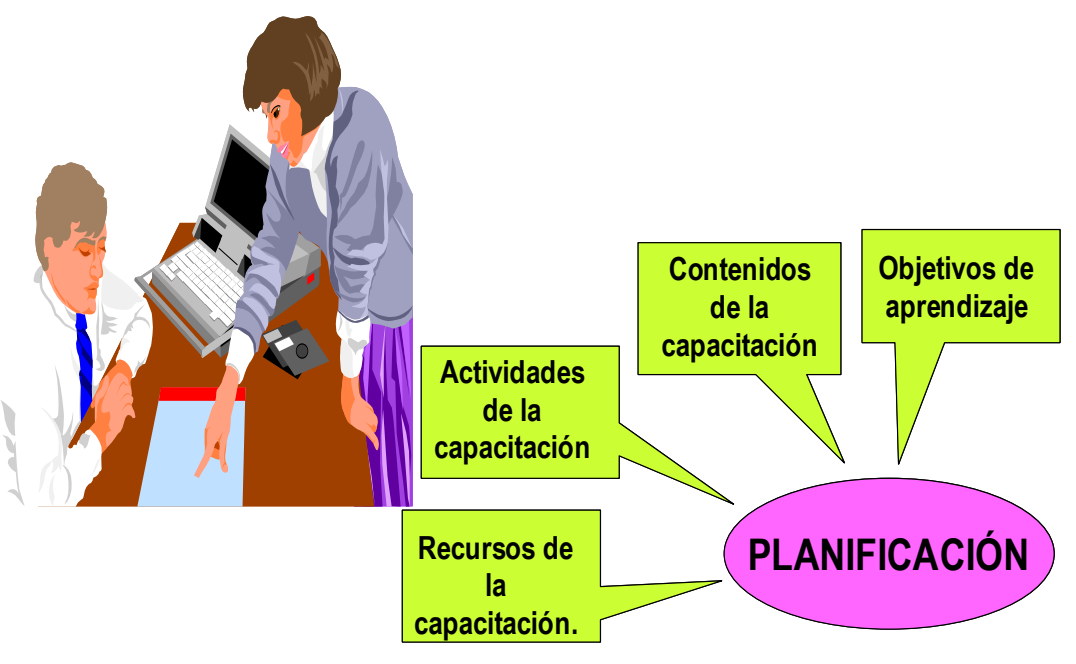




\section{GESTIÓN DE PROGRAMAS DE CAPACITACION}

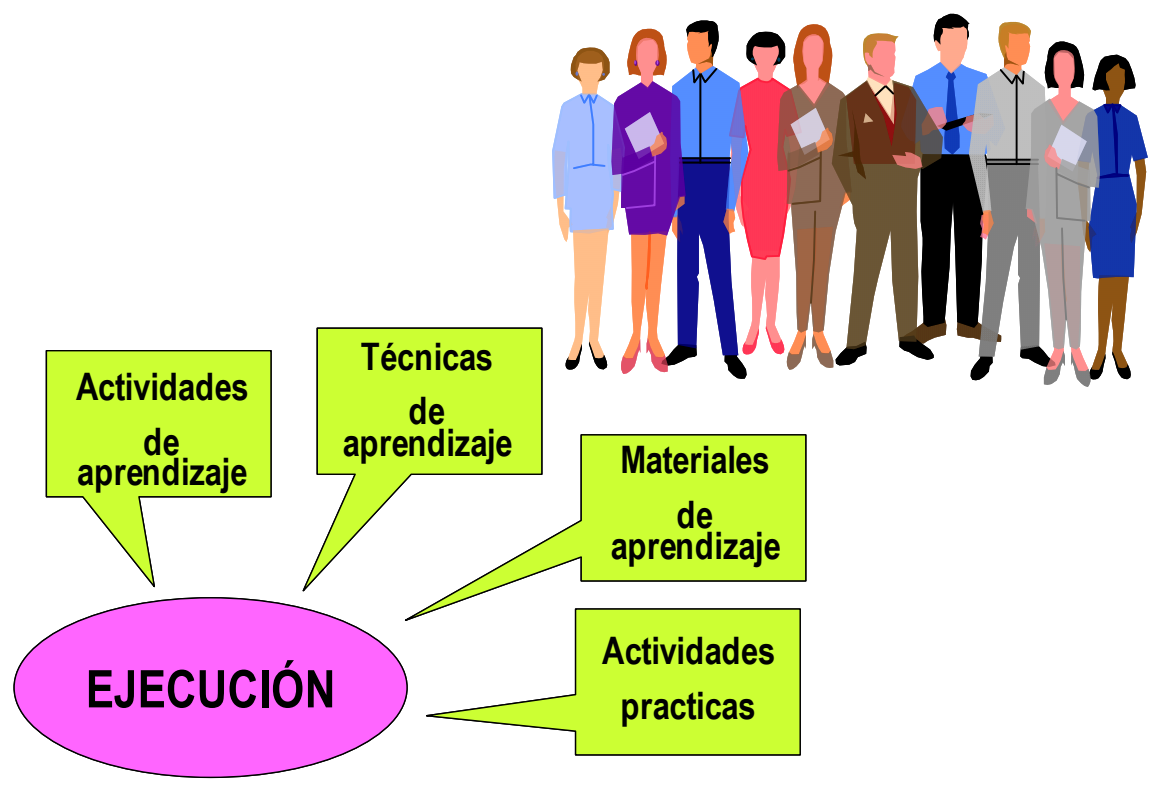

\section{GESTIÓN DE PROGRAMAS DE CAPACITACION}

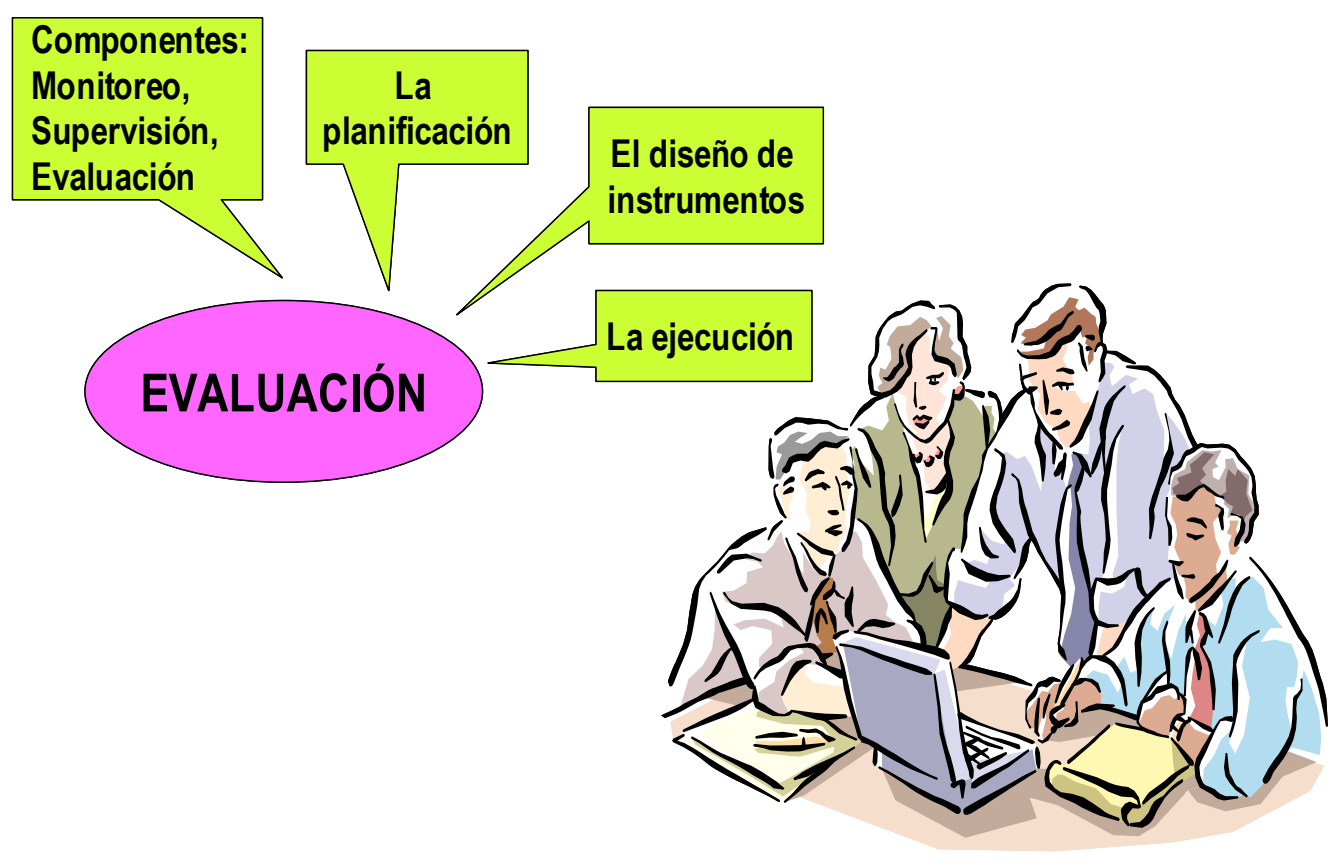



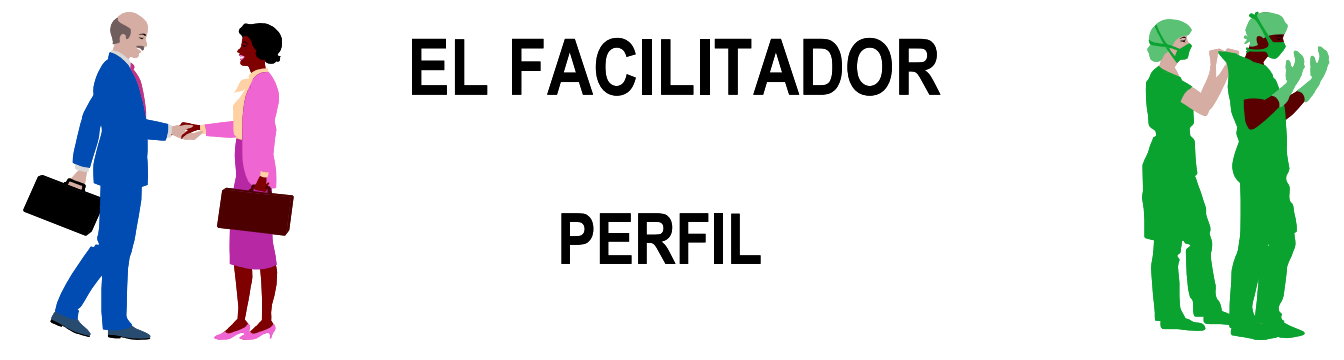

RETEN
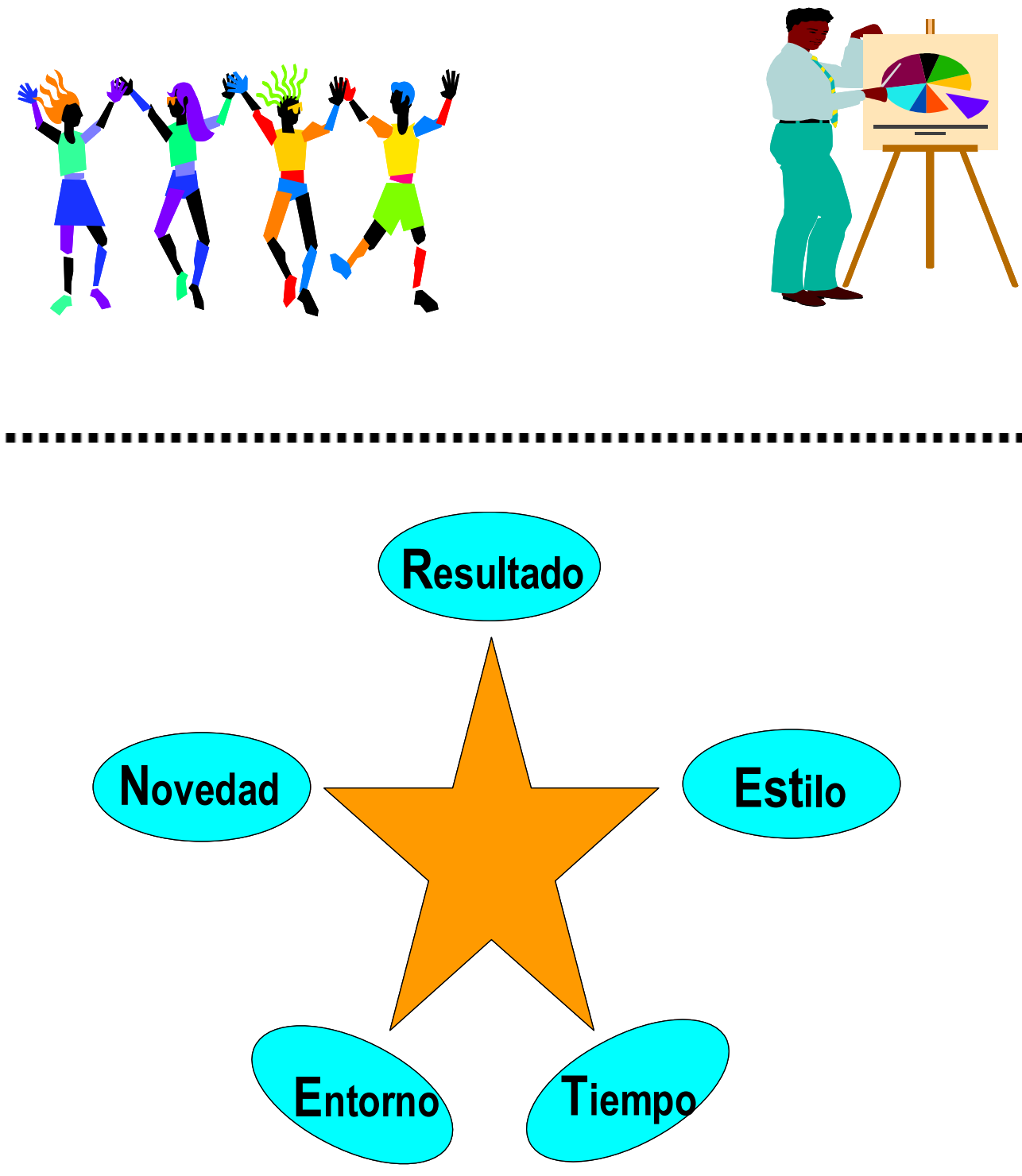


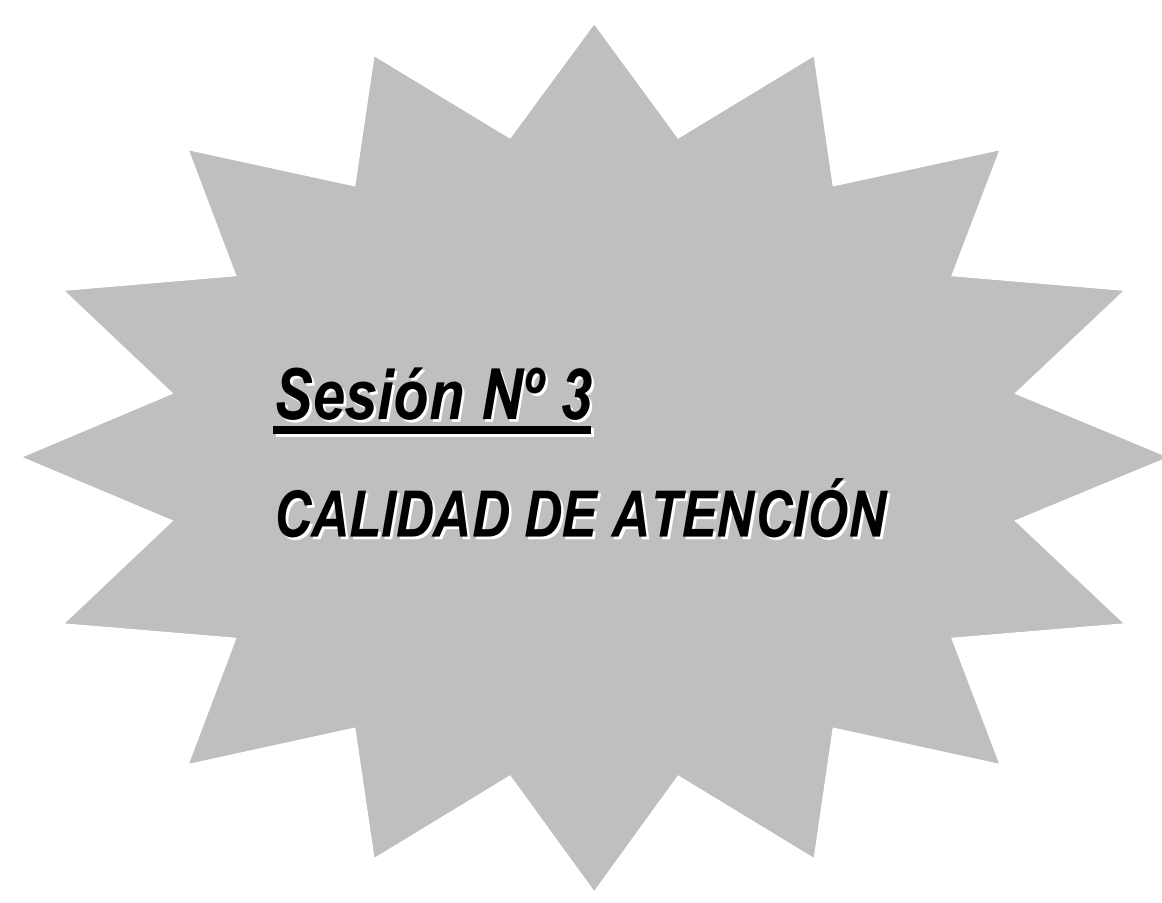

\section{CALIDAD}

Ofrecer los mayores beneficios a la salud con los menores riesgos a mayor cantidad de personas con los recursos disponibles.
Desempeño adecuado de intervenciones seguras, accesibles $y$ capaces de reducir: Morbilidad, mortalidad, minusvalía y desnutrición. 

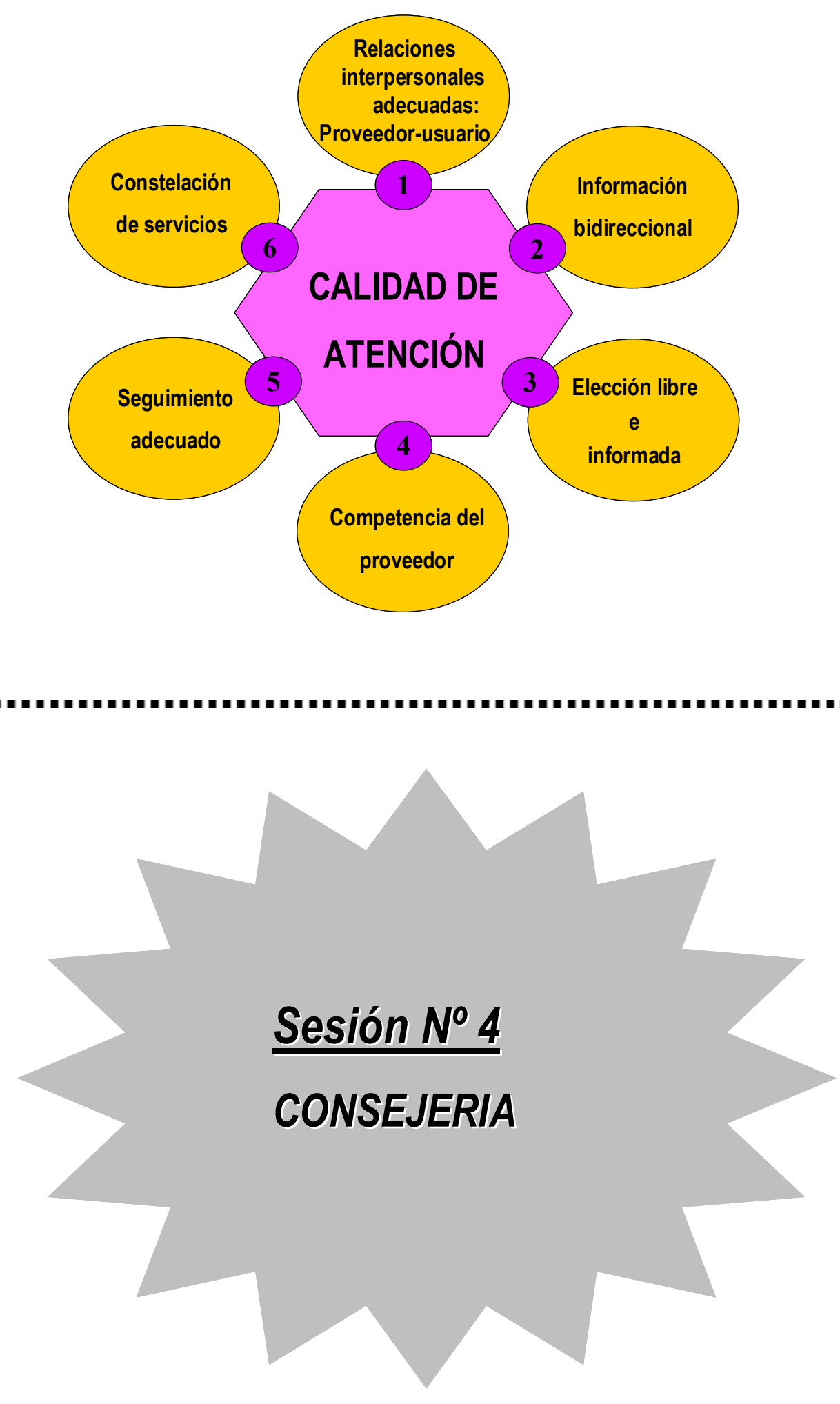


\section{PROCESO DE LA COMUNICACIÓN}

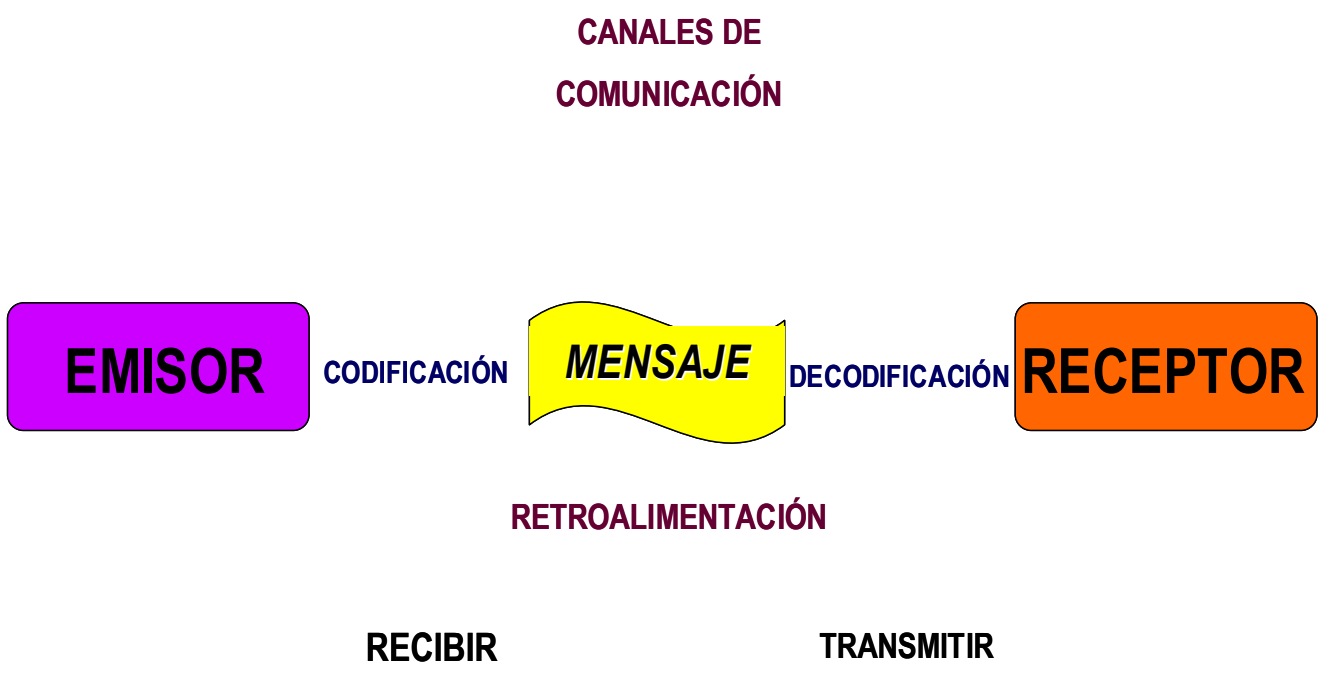

\section{CONSEJERIA}

Ayudar a las personas a que puedan tomar decisiones voluntarias $e$ informadas con respecto a su salud 


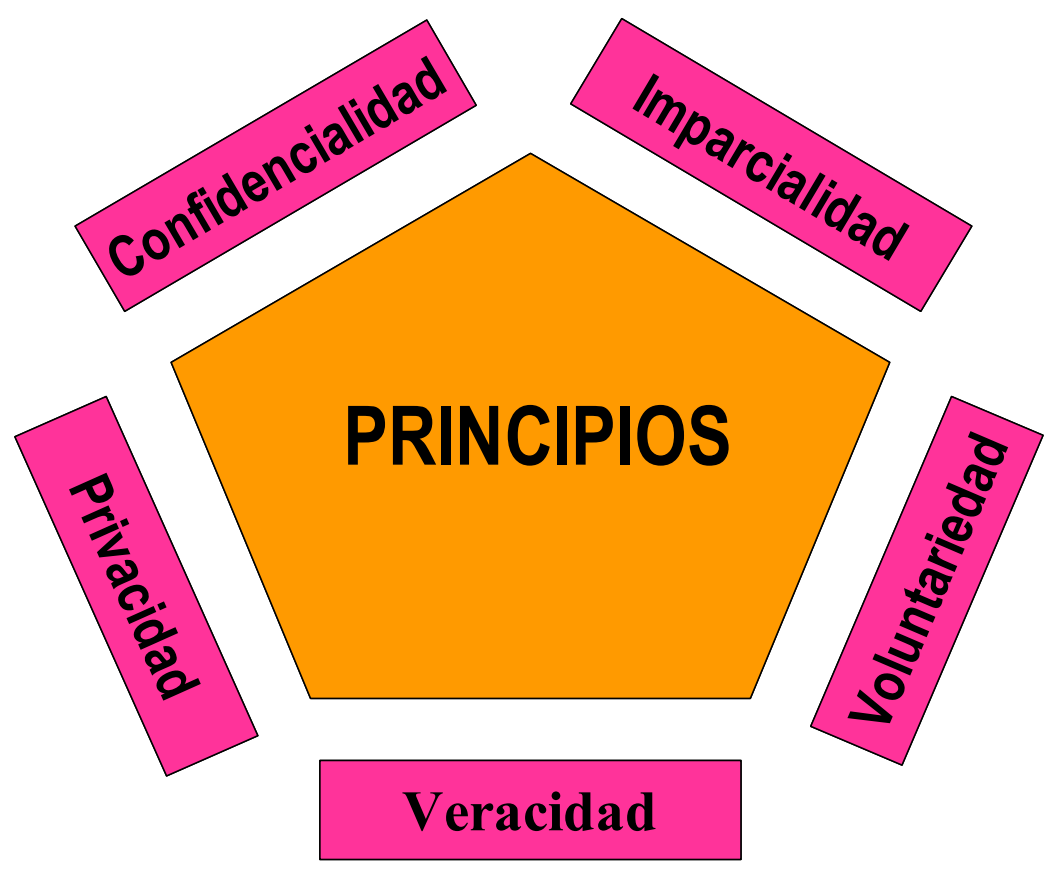

\section{Sesión $N^{0} 5$}

\section{CONSEJERIA BALANCEADA}

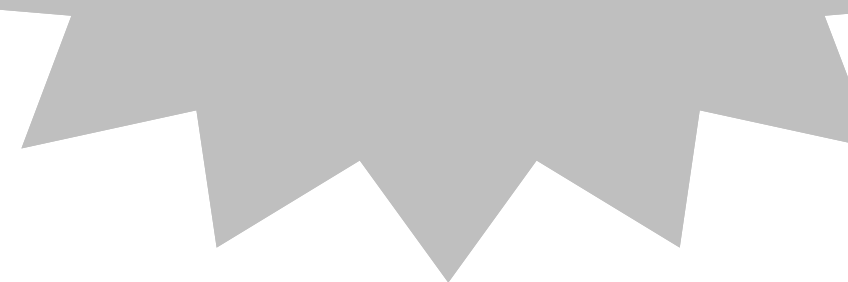




\section{APPENDIX 4: WORKSHOP AGENDA}




\section{CURSO TALLER DE FORMACION DE FACILITADORES EN "CONSEJERIA BALANCEADA"}

\section{Objetivo:}

- Contar con un Staff de facilitadores locales que permita difundir el uso de la metodología " Consejería Balanceada" y así mejorar la calidad de atención en los servicios del Ministerio de Salud de Guatemala.

DIA: 06 de Mayo de 2003.

\begin{tabular}{|c|c|c|c|c|}
\hline HORA & SESION & OBJETIVO & ACTIVIDAD & RESPONSABLE \\
\hline $\begin{array}{l}08: 30 \\
\text { A } \\
12: 00\end{array}$ & $\begin{array}{l}\text { Sesión No 1: } \\
\text { INTRODUCCIÓN }\end{array}$ & $\begin{array}{l}\text { - Que los participantes se } \\
\text { conozcan y } \\
\text { tomen acuerdos sobre los } \\
\text { objetivos de } \\
\text { la reunión. } \\
\text { - Que los participantes conozcan } \\
\text { los } \\
\text { resultados de las } \\
\text { investigaciones } \\
\text { realizadas. }\end{array}$ & $\begin{array}{l}\text { 1.1 Presentación y lectura del } \\
\text { programa. } \\
\text { 1.2 Presentación de } \\
\text { investigaciones } \\
\text { (MSPAS) realizadas en } \\
\text { octubre del } \\
2001 \text { y Junio del } 2002 .\end{array}$ & $\begin{array}{l}\text { I. R. } \\
\text { M.C } \\
\text { C.B. }\end{array}$ \\
\hline \multicolumn{5}{|c|}{$12.00 \mathrm{~A} 13.30$ ALMUERZO } \\
\hline $\begin{array}{c}13.30 \\
\text { A } \\
14.15\end{array}$ & $\begin{array}{l}\text { Sesión No 2: } \\
\text { GESTION DE LA CAPACITACION }\end{array}$ & $\begin{array}{l}\text { - Que los capacitadores } \\
\text { refuercen una } \\
\text { actitud de facilitadoras para la } \\
\text { ejecución de eventos de } \\
\text { capacitación. }\end{array}$ & $\begin{array}{l}\text { 2.1 Como aprenden los adultos. } \\
\text { 2.2 Diagnóstico y diseño de la } \\
\text { capacitación. }\end{array}$ & I.R \\
\hline $\begin{array}{c}14.15 \\
\text { A } \\
14.45\end{array}$ & & & $\begin{array}{l}\text { 2.3 Planificación de la } \\
\text { capacitación. }\end{array}$ & I.R \\
\hline $\begin{array}{c}14.45 \\
\text { A } \\
15.15\end{array}$ & & & $\begin{array}{l}2.4 \text { Ejecución y evaluación de la } \\
\text { capacitación }\end{array}$ & I.R \\
\hline
\end{tabular}




\begin{tabular}{|c|c|c|c|c|}
\hline $\begin{array}{l}15.15 \\
\text { A } \\
16.15\end{array}$ & & & $\begin{array}{l}\text { 2.5 El facilitador } \\
\text { 2.6 Perfil del facilitador. } \\
\text { 2.7 El RETEN: Técnica para la } \\
\text { preparación de eventos de } \\
\text { capacitación. }\end{array}$ & I.R \\
\hline \multicolumn{5}{|c|}{16.15 a 16.30 COFFE } \\
\hline $\begin{array}{l}16.30 \\
\text { A } \\
17.30\end{array}$ & $\begin{array}{l}\text { Sesión No 3: } \\
\text { CALIDAD DE ATENCION. }\end{array}$ & $\begin{array}{l}\text { - Reforzar conceptos sobre } \\
\text { calidad de } \\
\text { atención. } \\
\text { - Analizar la conección de la } \\
\text { consejería } \\
\text { con la calidad de atención. }\end{array}$ & $\begin{array}{l}\text { 3.1 Definición de calidad } \\
\text { 3.2 Elementos de la calidad. } \\
\text { 3.3 Elección libre e informada, } \\
\text { un } \\
\text { derecho fundamental. }\end{array}$ & I.R \\
\hline $\begin{array}{c}17.30 \\
\text { A } \\
18.00\end{array}$ & $\begin{array}{l}\text { Sesión NO 4: } \\
\text { LA CONSEJERIA }\end{array}$ & $\begin{array}{l}\text { - Reforzar conceptos básicos de } \\
\text { la } \\
\text { consejería. }\end{array}$ & $\begin{array}{l}4.1 \text { El proceso de } \\
\text { comunicación. } \\
4.2 \text { La consejería como } \\
\text { elemento } \\
\text { de importante para un servicio } \\
\text { de calidad. } \\
\text { 4.3 Principios de la consejería. }\end{array}$ & I.R \\
\hline
\end{tabular}


DIA: 07 de Mayo de 2003.

\begin{tabular}{|c|c|c|c|c|}
\hline HORA & SESION & OBJETIVO & ACTIVIDAD & RESPONSABLE \\
\hline $\begin{array}{c}08.30 \\
A \\
09.00\end{array}$ & $\begin{array}{l}\frac{\text { Continua }}{\text { Sesión No 4: }} \\
\text { LA CONSEJERIA }\end{array}$ & & 4.4 Pasos de la consejería. & I.R. \\
\hline $\begin{array}{l}09.00 \\
A \\
10: 30\end{array}$ & $\begin{array}{l}\text { Sesión No 5: } \\
\text { LA CONSEJERÍA BALANCEADA. }\end{array}$ & $\begin{array}{l}\text { - Que los participantes aprendan } \\
\text { el uso } \\
\text { del algoritmo y de las tarjetas. }\end{array}$ & $\begin{array}{l}\text { 5.1 Uso del tiempo e } \\
\text { información en } \\
\quad \text { forma efectiva y eficiente } \\
\text { en la } \\
\quad \text { consejería. } \\
\text { 5.2 Presentación del algoritmo. }\end{array}$ & $\begin{array}{l}\text { I.R. } \\
\text { B.S. } \\
\text { E.H. }\end{array}$ \\
\hline \multicolumn{5}{|c|}{$10.30 \mathrm{~A} 10.45 \mathrm{COFFE}$} \\
\hline $\begin{array}{c}10.45 \\
\mathrm{~A} \\
13.00\end{array}$ & & & $\begin{array}{l}\text { 5.3 Demostración de la consejería } \\
\text { con el } \\
\text { uso del algoritmo. } \\
\text { 5.4 Practica del uso del algoritmo }\end{array}$ & $\begin{array}{l}\text { I.R. } \\
\text { B.S. } \\
\text { E.H. }\end{array}$ \\
\hline \multicolumn{5}{|c|}{13.00 A 14.00 ALMUERZO } \\
\hline $\begin{array}{l}14.00 \\
\mathrm{~A} \\
16.00\end{array}$ & & & $\begin{array}{l}5.5 \text { Uso de material visual } \\
\text { "Tarjetas" que } \\
\quad \text { facilita el intercambio de } \\
\text { información } \\
\quad \text { proveedor cliente. }\end{array}$ & I.R. \\
\hline \multicolumn{5}{|c|}{$16.00 \mathrm{~A} 16.15 \mathrm{COFFE}$} \\
\hline $\begin{array}{c}16.15 \\
\mathrm{~A} \\
18.00\end{array}$ & & & $\begin{array}{l}\text { 5.6 Practica de la consejería con el } \\
\text { uso del } \\
\text { algoritmo, tarjetas y otros } \\
\text { materiales } \\
\text { de apoyo. }\end{array}$ & I.R. \\
\hline
\end{tabular}

DIA: 08 de Mayo de 2003.

\begin{tabular}{|l|l|}
\hline HORA & SESION \\
\hline
\end{tabular}




\begin{tabular}{|c|c|c|c|c|}
\hline $\begin{array}{c}08: 30 \\
\text { A } \\
10: 30\end{array}$ & $\begin{array}{l}\text { Sesión No 6: } \\
\text { REDEMOSTRACIÓN DE LA } \\
\text { CONSEJERÍA BALANCEADA. }\end{array}$ & $\begin{array}{l}\text { - Que los participantes se hagan } \\
\text { expertos en el uso de los } \\
\text { materiales y } \\
\text { puedan capacitar a otros. }\end{array}$ & $\begin{array}{l}\text { 6.1 Practica de la consejería con } \\
\text { el uso del algoritmo, tarjetas } \\
\text { y otros } \\
\text { materiales de apoyo. }\end{array}$ & M.C. \\
\hline \multicolumn{5}{|c|}{ 10.30 a 10.45: COFFE } \\
\hline $\begin{array}{l}10.45 \\
A \\
13.00\end{array}$ & & & $\begin{array}{l}\text { 6.2 Análisis de las } \\
\text { redemostraciones: } \\
\text { Aspectos positivos y } \\
\text { negativos } \\
\text { durante la practica. } \\
\text { 6.3 Propuesta para evitar } \\
\text { errores y } \\
\text { hacer más eficiente el uso } \\
\text { de } \\
\text { materiales. }\end{array}$ & I.R \\
\hline \multicolumn{5}{|c|}{ 13.00 A 14.00: ALMUERZO } \\
\hline $\begin{array}{c}14.00 \\
\text { A } \\
16.00\end{array}$ & & & $\begin{array}{l}\text { 6.4Practica de la consejería con } \\
\text { el } \\
\text { uso del algoritmo, tarjetas } \\
\text { y otros } \\
\text { materiales de apoyo. }\end{array}$ & I.R \\
\hline \multicolumn{5}{|c|}{ 16.00 A 16.15: COFFE } \\
\hline $\begin{array}{c}16.15 \\
\text { A } \\
18.00\end{array}$ & $\begin{array}{l}\text { Sesión N07: } \\
\text { PLAN DE CAPACITACION }\end{array}$ & $\begin{array}{l}\text { - Que el proyecto y los } \\
\text { participantes } \\
\text { cuenten con un plan de } \\
\text { capacitación } \\
\text { local. }\end{array}$ & $\begin{array}{l}\text { 7.1 Elaboración del plan de } \\
\text { Capacitación. }\end{array}$ & I.R. \\
\hline
\end{tabular}




\section{APPENDIX 5: PHASE III TRAINING SCHEDULE}

\begin{tabular}{|c|c|c|c|c|c|c|}
\hline & & \multicolumn{2}{|c|}{ Dates } & & & \\
\hline Health Area & Health District & Start & End & $\mathbf{N}$ & Supervisor & ATR/FA \\
\hline 1 Guatemala & Hospital Salud Mental & 02-Jul & 03-Jul & 20 & & \\
\hline 2 Suchitepequez & Escuela Aux. Mazatenango & 02-Jul & 03-Jul & 62 & & \\
\hline 3 Guatemala & CS \# 1 & 02-Jul & 03-Jul & 35 & & \\
\hline 4 Guatemala & Sta. Catarina Pinula & 02-Jul & 29-Jul & 8 & & \\
\hline 5 Guatemala & C.S. Boca del Monte & 03-Jul & 04-Jul & 15 & & \\
\hline 6 Guatemala & C.S.Chuarrancho & 05-Jul & 06-Jul & 15 & & \\
\hline 7 Guatemala & El Mesquital & 07-Jul & 10-Jul & 20 & & \\
\hline 8 Guatemala & C.S.ITS & 09-Jul & 10-Jul & 16 & & \\
\hline 9 Guatemala & C.S.Centro america & 09-Jul & 10-Jul & 16 & & \\
\hline 10 Guatemala & Sn. Miguel Petapa & 09-Jul & 10-Jul & 16 & & \\
\hline 11 Guatemala & Maternidad zona 13 & 10-Jul & 11-Jul & 9 & & \\
\hline 12 Guatemala & C.S. Villa Nueva & 10-Jul & 11-Jul & 27 & & \\
\hline \begin{tabular}{l|l}
13 & Peten Norte \\
\end{tabular} & Flores & 10-Jul & 11-Jul & 11 & & \\
\hline \begin{tabular}{l|l|}
14 & Peten Norte \\
\end{tabular} & Sn Francisco & 10-Jul & 11-Jul & 8 & & \\
\hline 15 Guatemala & Maternidad sta Elena & 12-Jul & 13-Jul & 12 & & \\
\hline $\begin{array}{ll}16 & \text { Guatemala } \\
\end{array}$ & C.S de Mixco & 12-Jul & 13-Jul & 26 & & \\
\hline \begin{tabular}{l|l|}
17 & Peten Norte \\
\end{tabular} & San Jose & 14-Jul & 15-Jul & 13 & & \\
\hline 18 Guatemala & Zona 6 & 15-Jul & 16-Jul & 30 & & \\
\hline 19 Guatemala & San Jose pinula & 15-Jul & 17-Jul & 4 & & \\
\hline 20 Guatemala & Maternidad el Amparo & 16-Jul & 17-Jul & 25 & & \\
\hline \begin{tabular}{l|l}
21 & Suchitepequez \\
\end{tabular} & Rio Bravo & 16-Jul & 17-Jul & 7 & & \\
\hline 22 Guatemala & Maternidad zona 13 & 17-Jul & 18-Jul & 9 & & \\
\hline $\begin{array}{lll}23 & \text { Guatemala } \\
\end{array}$ & C.S.San Jose Pinula & 17-Jul & 18-Jul & 15 & & \\
\hline \begin{tabular}{l|l}
24 & Peten Norte \\
\end{tabular} & Hospital San Benito & 17-Jul & 18-Jul & 5 & & \\
\hline \begin{tabular}{l|l|}
25 & Peten SurOccid \\
\end{tabular} & Libertad & 17-Jul & 18-Jul & 21 & & \\
\hline 26 Suchitepequez & Santo Domingo & 17-Jul & 18-Jul & 16 & & \\
\hline 27 Guatemala & El Milagro & 17-Jul & 18-Jul & 36 & & \\
\hline 28 Guatemala & Villa Canales & 18-Jul & 19-Jul & 20 & & \\
\hline $\begin{array}{ll}29 & \text { Guatemala } \\
\end{array}$ & Sn. Pedro Sac. & 18-Jul & 19-Jul & 20 & & \\
\hline 30 Guatemala & Maternidad 1 de julio & 19-Jul & 26-Jul & 15 & & \\
\hline 31 Guatemala & C.S.San Raymundo & 21-Jul & 22-Jul & 13 & & \\
\hline \begin{tabular}{l|l}
32 & Guatemala \\
\end{tabular} & PS Zona 3 & 22-Jul & 23-Jul & 28 & & \\
\hline 33 Guatemala & C.S.Zona 11 & 23-Jul & 24-Jul & 20 & & \\
\hline 34 Guatemala & CS.Zona 5 & 23-Jul & 24-Jul & 18 & & \\
\hline 35 Guatemala & C.S Tierra Nueva & 23-Jul & 24-Jul & 15 & & \\
\hline 36 Guatemala & C.S.Chinautla & 23-Jul & 24-Jul & 22 & & \\
\hline \begin{tabular}{l|l|}
37 & Peten SurOccid \\
\end{tabular} & Hospital Sayaxche & 23-Jul & 24-Jul & 6 & & \\
\hline 38 Peten SurOccid & C/S Sayaxche & 23-Jul & 24-Jul & 12 & & \\
\hline \begin{tabular}{l|l}
39 & Guatemala \\
\end{tabular} & C.S. Justo Rufino Barios & 24-Jul & 25-Jul & 12 & & \\
\hline 40 Guatemala & C,S. San pedro ayampuc & 24-Jul & 25-Jul & 20 & & \\
\hline 41 Suchitepequez & Chicacao & 24-Jul & 25-Jul & 7 & & \\
\hline 42 Suchitepequez & Hosp Nac Mazatenango & 24-Jul & 25-Jul & 17 & & \\
\hline 43 Suchitepequez & La Maquina & 24-Jul & 25-Jul & 9 & & \\
\hline 44 Suchitepequez & San Antonio & 24-Jul & 25-Jul & 16 & & \\
\hline \begin{tabular}{l|l}
45 & Suchitepequez \\
\end{tabular} & Santo Tomas & 24-Jul & 25-Jul & 13 & & \\
\hline
\end{tabular}




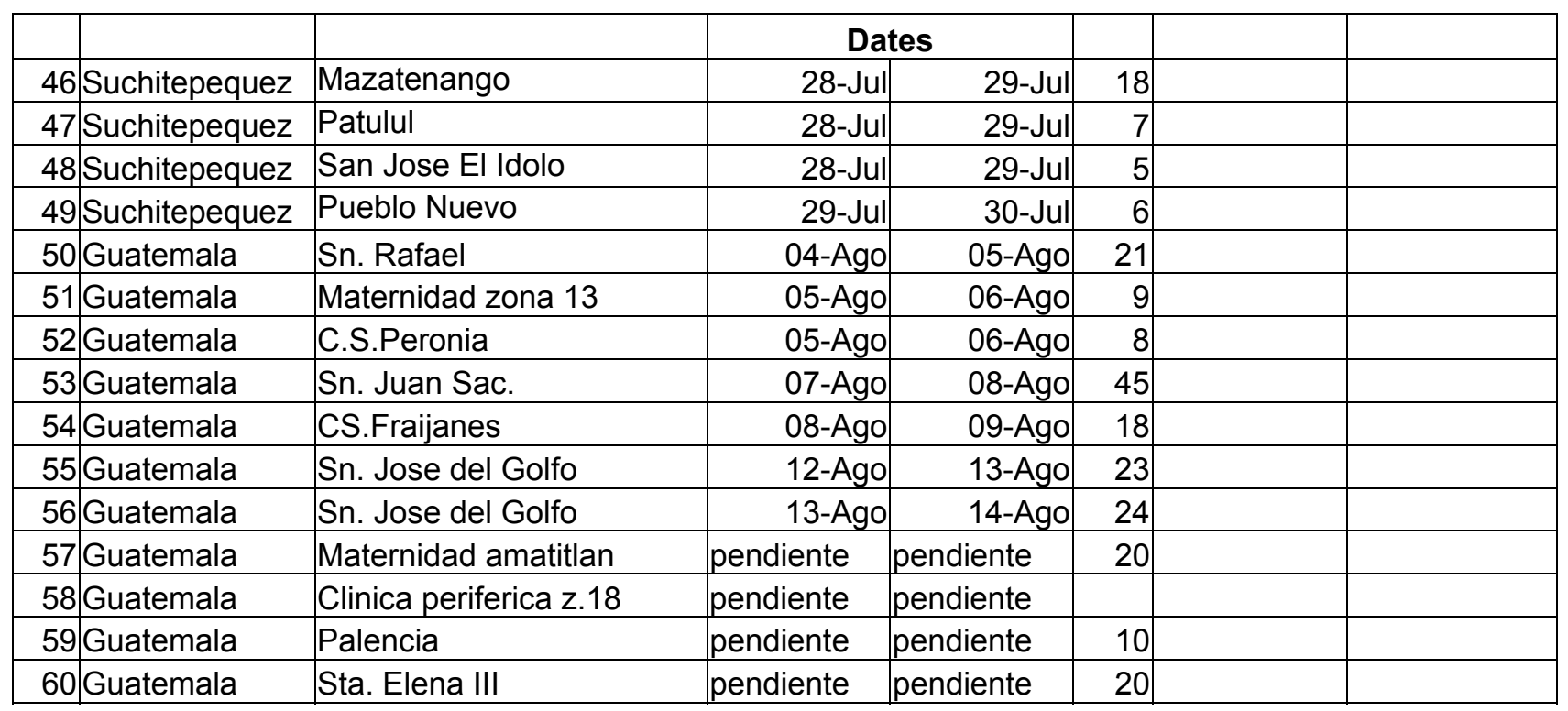




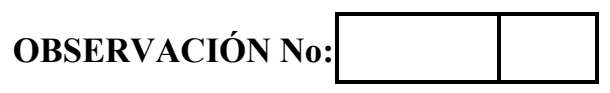

NOMBRE:

FECHA:

C/S:
CARGO:

HORA:

P/S:

\section{MUNICIPIO}

\begin{tabular}{|c|c|c|c|c|}
\hline No. & Criterio & SI & NO & OBSERVACIONES \\
\hline 1 & Bienvenida cordial & & & \\
\hline 2 & Desea planificación familiar & & & \\
\hline 3 & Descartó embarazo & & & \\
\hline 4 & Ya tiene un método elegido & & & \\
\hline 5 & Despligue de tarjetas & & & \\
\hline 6 & Quiere tener hijos en el futuro & & & \\
\hline 7 & Da de mamar a menor de 6 meses & & & \\
\hline 8 & Pareja coopera & & & \\
\hline 9 & Intolerancia a algún método & & & \\
\hline 10 & $\begin{array}{l}\text { Al descartar los métodos mencionó sólo los dos primeros } \\
\text { enunciados }\end{array}$ & & & \\
\hline 11 & Presencia de método en stock & & & \\
\hline 12 & Describir 4 características de los métodos no descartados & & & \\
\hline 13 & Agrupar los métodos no descartados por efectividad & & & \\
\hline 14 & Recomendar según el plazo que desea planificar & & & \\
\hline 15 & Pedir a la usuaria que elija un método & & & \\
\hline 16 & Revisar contraindicacioens & & & \\
\hline 17 & Describir mecanismos de acción & & & \\
\hline 18 & Describir modo de uso & & & \\
\hline 19 & Describir efectos secundarios & & & \\
\hline 20 & Describir signos de alarma & & & \\
\hline 21 & Verificar comprensión & & & \\
\hline
\end{tabular}




\begin{tabular}{|c|l|l|l|l|}
\hline 22 & $\begin{array}{l}\text { Pregunta para comprobar que usuaria mantiene la } \\
\text { elección }\end{array}$ & & \\
\hline 23 & $\begin{array}{l}\text { Consideró método de espera, doble protección si fuera el } \\
\text { caso }\end{array}$ & & & \\
\hline 24 & Instrucciones de seguimiento & & \\
\hline 25 & Despedida & & \\
\hline
\end{tabular}

